\title{
Moet die Afrikaanse Kerke skuld bely oor apartheid?: \\ Wat leer ons uit die Duitsers se worsteling \\ met skuld?
}

\author{
I W C van Wyk \\ Hoof: Hervormde Teologiese Opleiding \\ Tydelik-deeltydse dosent Departement Dogmatiek \\ en Christelike Etiek (Afd A) \\ Universiteit van Pretoria
}

\begin{abstract}
Should Afrikaans churches confess guilt for its share in apartheid? What do we learn from the German discussion?

This article asks the question whether the Afrikaans-speaking churches should confess guilt publicly for their support of the apartheid-state. A short summary is given to different opinions in South Africa. The main focus of the article is on the German discussion. From this discussion we learn that people, some in a more horrible way than others, do make themselves guilty in history. For believers it is a matter of course to confess their guilt in a church service. Guilty people, unfortunately, always try to justify themselves and to point to the guilt of others. Some people are always more guilty than others, but people become guilty collectively. To prevent evil, the church has the responsibility of preaching the doctrine of original guilt. This would also enable believers to handle guilt from the perspective of the doctrine of justification.
\end{abstract}

\section{INLEIDING}

Die beleid wat dekades lank wêreldwyd veroordeel, en deur die Afrikaaanse kerke ondersteun en verdedig is, word in ons dae tot die been toe ontbloot (Giliomee 1996a:9). Die onthullings wat tans oor die staatswese van die apartheidsera voor die Waarheids- en Versoeningskommissie (WVK) gemaak word, is só verdoemend dat mens nie kan verwag dat daar veel positief oor die bewindsjare van die Afrikaner gesê sal kan word nie. Onthullings soos die volgende vervul eerbare mense met weersin: martelings in aanhouding, moord op gevangenes, die afbrand van huise deur die polisie, verdwyning van mense, ontvoering van kinders (Beeld, 16 April 1996:1, 6, 8), 
massamoord in Langa 1960 (Beeld, 23 April 1996:6), gedwonge verskuiwings (Beeld, 25 April 1996:13), wrede moorde op regses en studente (Beeld, 3 Mei 1996:7), briefbomme vir geestelikes wat hulle met die ANC vereenselwig het (Beeld, 11 Junie 1996: 2), onskuldige teistering van mense, inhegtenisnemings (Beeld, 26 Julie 1996:4), 'n kind wat saam met ' $n$ valslik beskuldigde ma aangehou is en selfs vir dae sonder kos in afsondering gehou is (Beeld, 8 Aug 1996:4), wreedhede van die Vlakplaas-eenheid van die veiligheidspolisie soos deur die Eugene de Kock verhoor blootgelê is (Beeld, 17 Sept 1996), 7000 jeugdiges wat tussen 1960 en 1989 gesterf het (Beeld, 13 Junie 1997:2) ensovoorts, ensovoorts. Daar kan geen twyfel bestaan dat die onthullings van veral (oud)lede van die veiligheidsmagte voor die WVK, die hart van Afrikaner gaan uitruk nie. Afrikaners en die Afrikaanse kerke gaan beslis in groot morele krisis gedompel word (Rapport, 13 Okt 1996:7). Die vraag (Du Plessis 1997:13) wat aan die kerke gestel word is: hoe hanteer ons ons skuld? Een van die antwoorde wat van verskillende kante gegee word, is dat die Afrikaner en sy kerke minstens skuld moet bely. Oor die feit dat gelowiges skuld moet bely kan daar geen verskil van mening bestaan nie. Skuldbelydenis is wesenlik deel van die Christelike godsdiens. Die vraag is egter of die kerk skuld oor apartheid moet bely? Indien wel: wat en waar en met watter bedoelings en verwagtings? Op hierdie vrae word daar in die Afrikaanse kerke verskillende antwoorde gegee.

\subsection{Die reaksie van die kerke}

In die Nederduitsch Hervormde Kerk van Afrika word daar oor skuld en skuldbelydenis oor apartheid geswyg. My artikel (Van Wyk 1990) in Die Hervormer en opmerkings hier en daar in Konteks (De Beer 1996) is na my wete die enigste wat nog tot hiertoe op skrif gestel is. Of 'n Algemene Kerkvergadering of sy Kommissie nog amptelik gaan reageer, moet nog gesien word. Die besinning moet minstens begin. Ons het nie 'n ander keuse as om na ons eie verlede te kyk nie (Loader 1997:14).

Die 46ste Nasionale Sinode van die Gereformeerde Kerke in Suid-Afrika van 6-16 Januarie 1997 op Potchefstroom, is deur 'n beskrywingspunt van die Suidelike Partikuliere Sinode versoek om hom oor die vraag uit te spreek of die Gereformeerde Kerke 'n bepaalde aanspreeklikheid moet aanvaar vir die staatkundige-sosiale verlede van Suid-Afrika met betrekking tot die vestiging en uitvoering van die beleid van afsonderlike ontwikkeling of apartheid, en indien sodanige aanspreeklikheid bevestig of ontken sou word, wat die Here van die kerk in hierdie verband verwag'. Volgens Neels Smit (1997:10) het niemand op die Sinode vir 'n openbare skuldbelydenis gevoel nie. Daar is geargumenteer dat skuldbelydenis 'n persoonlike saak is en dat ' $n$ sinode nie vir die ganse kerk kan instaan nie. Verder is daar met herhaling gestel dat die 
Sinode nie namens die lidmate mede-aanspreeklikheid kan aanvaar vir die wandade wat deur die WVK blootgelê word nie. Politieke skuldbelydenisse pas volgens die Gereformeerdes (Die Kerkblad, 1997:7) ook nie by die kerk nie. Die kerk het die taak om die evangelie te verkondig, en neem daarom nie aan die politieke magstryd deel nie.

Binne die Nederduitse Gereformeerde Kerk woed daar nou weer 'n baie intense debat oor 'n openbare skuldbelydenis oor apartheid. Tydens die Algemene Sinodes van 1986 en 1990 het die NG Kerk skuld oor sy aandeel aan die apartheidsbeleid bely. Op 6 Nov 1990 het Willie Jonker namens die NG Kerk hierdie skuldbelydenis by die Rustenburg-kerkeberaad herhaal. Hierdie skuldbelydenis wat hy namens die NG Kerk gedoen het, was volgens hom moontlik gemaak deur die verandering in kerkbegrip binne die NG Kerk. Die ou kerkbegrip van die NG Kerk het op die gedagte neergekom dat die Kerk religieuse legitimeerder van die volkslewe en godsdienstige sanksioneerder van die volkstryd is. Hierdie ekklesiologie het die evangelie daarom ondergeskik gestel aan volksideale en Afrikanerbelange. Skuldbelydenis oor morele wandade was binne hierdie konteks nie moontlik nie, angesien dít volksverraad sou wees. Die nuwe kerkbegrip wat in die laaste jare binne die NG Kerk ontwikkel het, werk weer met 'n kritiese volksverbondenheid. Dit wil slegs kerk wees volgens sy eie belydenis. Die nuwe ekklesiologie wil verhoed dat die kerklike lewe tot maar net 'n sektor van die volkslewe afgradeer word. Daar word afskeid geneem van volksreligie en natuurlike teologie (Jonker 1991:94-98). Die belydenis van die sinode asook die herhaling en openbaarmaking daarvan deur Willie Jonker het groot ontsteltenis veroorsaak. Talle vrae word vandag oor die moontlikheid en wenslikheid van 'n politieke skuldbelydenis gevra. Die hooftrekke van hierdie debat word binne ' $n$ aantal temavelde behandel.

\subsection{Is (verdere) skuldbelydenisse oor apartheid nodig?}

Binne die NG Kerk is daar mense soos Ferdinand Deist (1993:81) wat meen dat die skuldbelydenis van die sinodes nie afdoende en voldoende is nie. Adrio König meen dat die belydenis van die sinode nie opreg en genoegsaam was nie, aangesien die belydenis nie by die sonde pas nie (König 1996:9). Met die oortuiging dat die skuldtema nie afgehandel is nie, is teoloë van die NG Kerk ywerig besig om begrondings te verskaf vir die politieke skuldbelydenisse wat nog moet kom. Dirkie Smit (1990, 1995, 1996) wys op die noodsaaklikheid en noodwendigheid van politieke skuldbelydenisse binne die kerk. Die misdaad van apartheid, waardeur die menslikheid van mense geskend is, moet volgens hom weer voor God en mense bely word (Smit 1995: 12). Daar moet nie verskonings gemaak en sondebokke gesoek word nie. Hierdie skuld moet net eenvoudig bely word. Müller (1993:175-179) meen ook dat die poli- 
tieke skuld van die lidmate van die kerk weer bely moet word. Indien dit nie gedoen wil word nie, sal dit 'n teken wees dat daar van die ware godsdiens af gevlug word. Hy waarsku teen vier afweermeganismes wat as argumente gebruik kan word om die kerk te verhoed om (weer) skuld oor apartheid te bely:

* Die spirtiualitiese afweermeganisme wat argumenteer dat die kerk hom nie met die politiek moet bemoei nie. Hierdie argument verraai net ' $n$ ander politieke mening en is juis ten diepste ook 'n politieke daad.

* Die pastorale afweermeganisme wat sê dat die gemeente 'n plek is vir beskerming en vertroeteling, met ander woorde, 'n wegkruipplek van die ware lewensprobleme.

* Die afweermeganisme van die sonde. Deur veralgemening en komplisering moet almal se skuld onderstreep word. Op hierdie manier word van die eie skuld weggehardloop.

* Die afweermeganisme van die verdringing. Die argument word gevoer dat mense nie skuldenaars is nie, maar bloot onskuldige slagoffers.

In aansluiting by Calvyn (Inst III, 4, 10) meen sekere Gereformeerde teoloë dat ook die Gereformeerde Kerke, op grond van die sinodebesluite van 1970 tot 1985 waarin daar ondersteuning vir die apartheidsbeleid uitgespreek is, in die openbaar skuld moet bely (Van Wyk 1997:24). Aan die ander kant van die spektrum is daar weer mense soos Gert Jordaan (1996:5) wat meen dat dit sinneloos is om skuld te bely oor apartheid. Die konsekwensie sal wees dat daar in die toekoms weer en weer sulke openbare skuldbelydenisse opgevoer sal moet word, aangesien die onreggeskiedenis voortgaan. Sommige Afrikaners (veral hulle wat deel is van die NG Kerk wat reeds skuld bely het) meen weer dat daar nou genoeg skuld bely is en weier om verder skuld te bely. Verdere verwagtinge om skuld te bely kom neer op 'n sadistiese begeerte om die Afrikaner te trap (Le Roux 1996:24, 130). Afrikaners wil in hulle binnekamer skuld bely, want hulle wil aan God en nie aan die verontregtes uitgelewer wees nie (Le Roux 1996:31). Hulle wil eerder wegvlug in die doen van die liefde. Hulle wil nou eerder begin om reg te maak wat verkeerd geloop het (Le Roux 1996:32). Dit raak ook al duideliker dat Afrikaners nie nou skuld wil bely oor die verlede nie, omdat hulle die slagoffers van die hede geword het (Rapport 27 Okt 1996:14). Nuwe ongeregtighede (regstellende aksie) wek weersin in skuldbelydenisse (Le Roux 1996:27). 


\subsection{Wat moet bely word?}

Dit blyk dat diegene wat openbare skuldbelydenisse wil doen of alreeds gedoen het, redelik eenstemmig is oor die sondes wat bely moet word. Dit is die nalatingsondes van die Afrikaanse kerke wat bely moet word. Daar word geoordeel dat ons skuldig is omdat ons nie getuig het toe ons moes nie, nie teen onreg, rassistiese gesindhede en aantasting van menswaardigheid getuig het toe ons moes nie, en dat ons toegelaat het dat apartheid ons onsensitief gemaak het vir lyding van andere. Ons prediking was só vergeestelik dat ons eie lidmate onder ons prediking gesit en moord bedink het en die evangelie nie gehoor het nie. Die mening word uitgespreek dat die kerke skuldig is omdat hulle verantwoordelik was vir die ideologiese raamwerk waarbinne skendings plaasgevind het (Die Kerkbode, 18 Okt 1996:1; 20 Junie 1997:6).

\subsection{Wie moet almal bely?}

Wie is almal skuldig? Is die kerk as kollektief, is die volk as kollektief, is die party as kollektief skuldig? Rondom hierdie vraag gaan die menings wyd uiteen. Die interessante in die huidige debat is dat niemand minder as president Mandela die gedagte van kollektiewe skuld afwys. Die Afrikaner as groep is volgens hom nie in die aanklagbank nie. Dit is net sekere kriminele. In sy eie woorde:

Daar is geen plek vir enige opvatting dat enige rasse-, etniese-, taal-, godsdienstige of ander groep kollektief in die beskuldigdebank is nie .... Want soos met ander taal- en kultuurgemeenskappe, is dit nie in die aard van die Afrikaner as sodanig om so wreedaardig teenoor andere te wees nie.

(Beeld, 16 April 1997:1)

Aan die ander kant is daar die mening dat daar wel van kollektiewe skuld sprake is. Gewone kerklidmate meen dat almal binne die Afrikanerdom, ook die huisvroue, skuldig is aan wat gebeur het. Ons skuld is die 'ten koste van ander'. Ander het onder ons oë van ellende vergaan. Ons (almal) het mense se gees gekwets (Le Roux 1996:2930, 103-104). Teoloë in die Gereformeerde Kerke val by hierdie argument in en sê dat almal wat deel van die 'sisteem' en struktuur was, skuldig is. Almal wat passief was, almal wat nagelaat het om weerstand te beoefen is 'lessenaarmisdadigers' en is skuldig. Nie net hulle wat wetlik aanspreeklik is, is skuldig nie. Ook hulle wat by alles gebaat het en gemeen het dat hulle nie nodig het om verantwoordelikheid te aanvaar, of dat hulle nie tot verantwoording geroep sal word nie, is skuldig (Van der Walt 1996b:11, 
12, 19). Met beroep op Calvyn word daar daarom gepleit vir 'n kollektiewe skuldbelydenis deur die volk (Van Wyk 1997:24-25). Nie net Calvyn nie, maar ook die Skrif self word nader getrek. Met behulp van Skrifgedeeltes soos Daniël 9:1-9, Nehemia 1:4-10 en Nehemia 9:1-3 word geargumenteer dat ons nie van die gedagte van kollektiewe skuld moet probeer wegkom nie, aangesien dit deel van die Bybelse boodskap is (Koornhof 1996:14). Hierdie standpuntinname word deur teoloë uit die Engelse kerke aangemoedig. Op grond van die insigte van Karl Jaspers toon De Gruchy (1993:4-7) aan dat die skuldnetwerk wat vir hierdie 'misdaad teen die mensdom' verantwoordelik was, onder 'n groot deel van die blanke gemeenskap bestaan.

\subsection{Waar moet skuld bely word?}

Die menings gaan ook rondom hierdie vraag in verskillende rigtings. Die een mening is dat daar alleenlik binne kerklike ruimtes soos eredienste of sinodevergaderings skuld bely moet word (Jordaan 1997:5). Die ander mening is dat daar buite kerklike ruimtes, en verkieslik voor ' $n$ instansie soos die WVK skuld bely moet word. Oor hierdie voorstel word daar heftig getwis. Die voorstanders van 'n skuldbelydenis voor hierdie kommissie (en ander soortgelyke kommissies wat later in die lewe geroep mag word) voer aan dat hierdie geleenthede aangegryp moet word aangesien dít geleenthede is om 'n beter toekoms te help bou. Die kerk moet deel wees van die vertel van waarheid, die belydenis van skuld en die vergewings- en versoeningsprosesse wat dár bewerk word (Van der Walt 1996b:15-19). Swartmense sien belydenis en versoening as 'n voortgaande proses. Daarom kan daar nie volstaan word met die skuldbelydenisse van die Algemene Sinodes van 1986 en 1990 nie (Müller 1996:13). Etienne de Villiers (1996:143) sien skuldbelydenis voor staatskommissies as deel van die kerk se profetiese roeping om versoening in die samelewing te help bevorder. Die voorstanders van hierdie kommissies wys daarop dat hierdie prosesse ' $n$ baie beter alternatief is as Nürnberg tipe verhore, aangesien amnestie beter is as vervolging (De Villiers 1996:144-145; Beeld, 16 April 1996:13). Volgens Alex Boraine sê die WVK nee vir geheueverlies en ja vir herinnering, nee vir volskaalse vervolgings en ja vir vergifnis. Volgens hom is vergifnis beter as wraak en bitterheid (Beeld, 27 Aug 1996:11). Die oproep word gedoen dat die kerke nie by die sittings van 'n kommissie soos die WVK moet wegbly nie, aangesien swartmense dáár oor hulle ervarings praat. Dár word die emosies van swartmense uitgespoeg. Indien Afrikaners nie in hierdie prosesse saamwerk nie, sal daar geweldige negatiewe gevoelens teen hulle ontstaan, wat baie sleg vir hulle posisie in die toekoms van hierdie land sal wees (Esterhuyse 1996:14). 'n Kommissie soos die WVK neem ook die plek van rou- en begrafnisrituele in, aangesien daar nie begrafnisse 
vir talle van die slagoffers was nie (Beeld, 9 Aug 1996:17). Deelname aan die werksaamhede van die WVK het volgens Piet Meiring (1996:10) die waarde dat swartmense die gevoel mag kry dat die Afrikaanse kerke uiteindelik vir hulle as mense omgee.

Die teenstanders van 'n kerklike skuldbelydenis voor 'n instansie soos die WVK voer weer die volgende argumente aan: 'n skuldbelydenis is net moontlik op grond van die belofte van vergewing. Om hierdie rede behoort gelowiges skuld te bely waar hulle vergewing, en nie amnestie verwag nie (Smit 1995:12). Voor staatsinstellings kan die kerk ook onkerklik met skuld omgaan. Die kerk kan daar tegnies skuld op hom neem, ter wille daarvan om van skuld ontslae te raak. Die 'mae culpa-cop out gedagte' kan juis op 'n plek soos hierdie sy kop uitsteek. 'n Openbare skuldbelydenis kan juis ook 'n strategie wees om ware berou te ontduik (Smit 1990:278, 1995:14). Volgens Ben Engelbrecht (1996:10) bely die kerk skuld net voor God, en nie voor selfaangestelde regters nie, want net Hy kan die kerk se skuld vergewe. Volgens hom moet die NG Kerk sy oordeelsfoute erken en aangaan met sy werk. Die spel van religieuse politiek moet nie saam met die bevrydingsteologie gespeel word nie, aangesien die nuwe politiek nog meer boos gaan wees as die ou politiek. Die feit dat die voorsitter van die WVK, Desmond Tutu self nie bereid is om jammer te sê nie, wek weersin in kommissies soos hierdie (Die Kerkbode, 15 Nov 1996:20). Afgesien van die teologiese probleme, is daar talle ander besware teen 'n kommissie soos hierdie. Die groot beswaar is dat dit 'n politieke speelbal van die regerende party is (Smit 1995:15). Die ander politieke partye kla dat die WVK nie onpartydig is nie en dat dit ' $n$ instrument van selfregverdiging van die ANC is (Beeld, 6 Junie 1996:2). Die verdere klag is dat die waarheid van die verlede op ' $n$ Manicheistiese wyse verdeel word in die boosheid wat met apartheid te make gehad het en die goeie wat met die stryd téén apartheid te make gehad het (Beeld, 16 April 1996:13; Muller 1996:15; De Villiers 1996:22; Latakgomo 1996:6). Om hierdie rede verwerp iemand soos Adam Small (Le Roux 1996:25) die aansprake op waarheid deur die WVK met minagting. Breyten Breytenbach (Beeld, 8 Okt 1996:7) maak selfs die volgende uitspraak: 'Die WVK, daardie lieg-en-biegplek met die wit gepleisterde grafte se seënende gemeesmuil, het weinig te doen met waarheid of versoening'. Die uiteinde van die hele debat is dat die Algemene Sinodale Kommissie van die NG Kerk, (voorlopig) soos die ander Afrikaanse kerke, besluit het om nie skuld voor die WVK te bely nie (Die Kerkbode, 16 Aug 1996 Beeld, 23 Mei 1997:1).

\subsection{Wat is die verwagtinge rondom 'n politieke skuldbelydenis?}

Die voorstanders van 'n openbare skuldbelydenis oor apartheid meen dat só 'n belydenis die eer en aansien van die Gereformeerde teologie moet help red (Deist 1993:78). Dit moet met die verwagting en hoop gedoen word dat hulle, wie ons 
verontreg het, ons sal vergewe (Deist 1993:84). Skuld moet nie met die verwagting bely word dat die nuwe aarde sal aanbreek nie (Deist 1993:83), maar dat dit minstens die begin van die proses van restitusie of regstelling sal wees. 'n Skuldbelydenis moet dus die begin wees van aksies, wat nie tot die verbetering van die prediking sal lei nie, maar tot die uitskakeling van sosio-ekonomiese ongelykheid in die land (Deist 1993:85; Van der Walt 1996b:15-19; Die Kerkbode, 20 Junie 1997:6). Die herstrukturering van die samelewing en die herstel van humaniteit kan dus net met 'n skuldbelydenis begin (De Gruchy 1993:10-13). Desmond Tutu (Beeld, 8 Mei 1996:6) en Peter Storey (Beeld, 17 Junie 1996:13) belowe vergewing en 'n belangrike rol vir Afrikaners in die 'nuwe Suid-Afrika' indien hulle skuld sou bely (Beeld, 8 Mei 1996:6). Die verwagting is dus die keer van wraak en die skep van 'n versoende samelewing (Van der Walt 1996b:10).

\section{DIE BYDRAE VAN DIE DUITSE DISKUSSIE TOT ONS PROBLEMATIEK}

Dit is duidelik dat die Afrikaanse kerke met talle vrae en probleme gekonfronteer word waarop hulle nie voorbereid is nie. Gelukkig is die kerk, as liggaam van Christus, katoliek. Ons kan dus lig soek by 'n ander kerk in 'n ander tydperk. Die Düitse Evangeliese Kerk is al reeds deur hierdie krisis van politieke skuldbelydenis. Ons sal daarom dwaas wees indien ons nie uit hierdie kerk se teologiese debat wil gaan leer nie. Ek gaan nie die metode volg om telkens na ons debat terug te verwys nie. 'n Noukeurige leser sal opmerk dat alles in die Duitse debat (wat ek ter sprake bring) met ons problematiek te make het.

\subsection{Die skuldtema tot ná die Eerste Wêreldoorlog}

Die Duitse Protestantisme is sedert Luther al vir eeue lank besig om oor skuld en skuldbelydenis na te dink. Uit hulle besinning oor boetedoening, bieg en skuldvergewing (Peters 1984) kan mens geweldig baie te wete kom oor ons tema. Weens 'n gebrek aan ruimte kan daar slegs op die skulddebat sedert die Eerste Wêreldoorlog gekonsentreer word. Politieke skuldbelydenisse is 'n baie jong verskynsel. Geen skuldbelydenisse is gedoen ná die oorloë van 1813/15, 1866, 1870/71 nie. Inteendeel! Al wat 'n mens teëkom is regverdigingspogings van die oorloë. Slawehandel en kolonialisme het ook nie diepe nadenke oor skuldverstrikkings opgelewer nie. Die eerste keer dat oorloë en konflikte moreel beoordeel is, is tydens die Haager ontwapeningskonferensies van 1899 en 1907. Ná die Eerste Wêreldoorlog was die oorwinnaars nie tevrede met net 'n militêre oorwinning nie. Hulle het ook gesmag na 'n morele oorwinning. Daarom is die oorlog moreel beoordeel met 'n morele maatstaf wat hulle self bepaal het, naamlik 
die oorwịnning as prinsiep van geregtigheid. Die uiteinde van die corlog was dus die kriterium vir morele geloofwaardigheid. Duitsland was dus alleen skuldig. Dit was veral die Franse en Amerikaners wat op hierdie manier gedink en geoordeel het. Interessant is dat die Engelse en Skandinaviërs nie tot hierdie konklusie gekom het nie. Alreeds in die somer van 1919 het die Duitsers voor die 'Wêreldbond vir Vriendelike Samewerking van Kerke' in Oud Wassenaar in Nederland die eerste keer politieke skuld bely. Friedrich Siegmund-Schulze en vier ander Duitsers het dáár namens die Duitse Kerk skuld bely, en erken dat die skending van België se neutraliteit moreel verkeerd was. Soos te wagte het 'n groot storm oor hierdie manne losgebars. Vir sommiges was daar te veel, en vir ander te min bely. Die uiteinde was, dat die skuldvraag in die Duitse teologie van die tafel gevee is. As gevolg hiervan het die wrok tussen veral die Duitsers en Franse bly voortlewe.

\subsection{Menings oor skuld tydens die Tweede Wêreldoorlog}

Dietrich Bonhoeffer het geweldige groot invloed op die Belydende Kerk en die naoorlogse Duitse teologie uitgeoefen. Dit kan daarom baie leersaam wees om na sy opvattings van skuld en skuldbelydenis te kyk. Hy het hom alreeds in 1930 in sy proefskrif Sanctorum Communio oor die Duitse skuld uitgespreek. Van belang vir ons is dat hy vroeg in sy lewe alreeds die gedagte aanvaar het dat nie net enkelinge skuldig is nie, maar dat die hele volk en kerk medeskuldig is aan die onreg wat aan die opbou was. In 1941 laat hy hom weer uit oor hierdie tema. Onder die opskrif Schuldubernahme (kyk Bonhoeffer 1966:225-256) verwerp hy die aanklag dat hy daarop uit is om deur die uitwys van 'algemene skuld' die hele volk te verneder deur hulle van hulle morele integriteit te beroof. Sy oproep tot die besef van 'algemene skuld' is op die verwesenliking van die liefde gemik. Die besef van 'algemene skuld' moet volgens hom in skuldoorname uitmond. Wanneer gelowiges ander se skuld op hulle neem, het ons met die hoogste vorm van vryheid en van liefde te make. Liefde is volgens Bonhoeffer dus nie die poging om onskuldig te word deur jou met die slagoffer te identifiseer nie, maar om saam met die skuldige te ly. Liefde wat mense in hulle skuld alleen wil laat, is nie liefde nie. Vanuit hierdie perspektief kon Bonhoeffer nooit verdink word van volksverraad nie. Sy begrip van algemene skuld het neergekom op die hoogste vorm van volksliefde. Onder die opskrif Das Schuldbekenntnis (Bonhoeffer 1966: 117-123) het hy ook die volgende gesê oor die skuldproblematiek. Skuld is nie die oortreding van 'n abstrakte wet nie, maar die afval van Christus. Kennis van skuld groei slegs deur ' $n$ groei in kennis van Christus en wel van sy genade. Kennis van skuld is daarom slegs binne die kerk moontlik, aangesien slegs dár van Christus geleer word. Belydenis van skuld kan daarom ook net binne die kerk gedoen word. Mense 
wat binne die kerk skuld bely, kyk nie na die skuld van mede-gelowiges nie. Hulle soek nie na minder of meer skuld nie, aangesien daar binne die kerk nie ruimte vir selfgeregtigheid is nie. Om hierdie rede moet daar nie na enkele oortredings gekyk word nie, maar na die skuld aan Jesus Christus. Deur op Christus se genade te konsentreer, kan daar net op die eie skuld gekonsentreer word. Daar word ook nie verder na groter en kleiner sondaars gesoek nie. Ook nie na die regte en gepaste vergelding nie (Bonhoeffer 1966:117-119). Die kerk bely sy skuld volgens Bonhoeffer aan die hand van die oortreding van die Dekaloog. Die Dekaloog is nie 'n argaiese dokument nie, aangesien elke gebod relevant is vir elke epog. Daarom het hy die Dekaloog op 'n wyse geaktualiseer dat elke lidmaat (maar veral die 'Duitse Christene') kan insien dat hulle skuldig is aan die gebod van God (Bonhoeffer 1966:120-123).

Hans Asmussen was een van die opstellers van die Stuttgartse skuldbelydenis en leidinggewende kerkman direk ná die oorlog. Dit is daarom vanselfsprekend dat ons na hierdie man se vroeë uitsprake oor skuld en skuldbelydenis sal kyk. Visser't Hooft het al tydens die oorlog namens die Ekumene met Asmussen as leidinggewende figuur binne die Duitse Kerk kontak gemaak. Die Ekumene was van plan om bande met die Duitsers ná die oorlog herstel. Daar is besef dat die Duitse bevolking hulp in terme van kosvoorrade gaan benodig. Daar was egter ' $n$ voorwaarde gekoppel aan die herstel van bande en die organisering van hulp, naamlik die belydenis van skuld - nie net die skuld wat deur Nazi's veroorsaak is nie, maar ook die nalatingsondes van die kerk. Om hierdie rede het Visser't Hooft gevra dat Asmussen aan hom sy verstaan van skuld en skuldbelydenis moet verduidelik, sodat daar besluit kan word of hulle in die Ekumene met die voorbereidingswerk kan voortgaan.

Op 13 Desember 1942 skryf Asmussen dan aan Visser't Hooft 'n brief waarin hy sy standpunte verduidelik. Volgens Siemens is hierdie brief onlosmaaklik deel van die voorgeskiedenis van Stuttgart. Visser't Hooft het selfs op 9 Oktober 1947 daarop gewys dat hierdie brief die eintlike basis en verwysingsraamwerk gevorm het vir die samekoms in Stuttgart. Asmussen het ter aanvang vir begrip gepleit dat dit vir die Duitsers moeilik en sensitief is om skuld te bely. Hy wys daarop dat daar ná die Eerste Wêreldoorlog eensydig skuld op die Duitsers gelaai is. Wie dit daarom in daardie jare gewaag het om oor skuld te praat, is as 'n vaderlandsveragter afgemaak. Die Ekumene moes hierdie problematiek goed begryp. Daarom sou hy ook ná die voorlees van die Stuttgartse skuldbelydenis gewaarsku het teen 'n politieke misbruik van 'n skuldbelydenis. Die tweede belangrike uitspraak wat Asmussen in hierdie brief gemaak het, was oor algemene skuld. Asmussen het toegegee dat buitelandse Christene reg is wanneer hulle beweer dat die Duitse Christene mede-skuldig is aan die Duitse oorlogskuld. Op grond van die deel-wees-van-die-volk het hy besef dat hy skuldig is, ten spyte van sy persoonlike onskuld. Hy wil nie net skuld bely oor die verkeerde beslissings van sy 
kerk nie, maar moet as Duitser (dít is God se beskikking vir hom) ook die skuld van Duitsland op sy skouers laai (Siemens 1987:63). Sy derde uitspraak het oor skuldbelydenis teenoor mense gehandel. Asmussen het besef dat 'n skuldbelydenis teenoor mense jou onvry maak. Dié een wat jou belydenis aanhoor, kan oor jou beskik.

Om hierdie rede het hy (Siemens 1987:64-68) die Ekumene aan drie evangeliese grondwaarhede herinner:

* Om 'n skuldbelydenis aan te hoor mag nie jou eie gevoel van morele meerderwaardigheid bevestig nie, maar moet jou besef van mede-skuldigheid bevorder. Om hierdie rede moet 'n skuldbelydenis binne die kerk gedoen word en nie binne die ruimte van die politiek nie. Alleen dáár sal daar aan hierdie voorwaarde voldoen word. Binne die kerk mag daar ook nie op die openbaarmaking van alles en nog wat aangedring word nie, aangesien die priesterlike dienskarakter van die amp daardeur geskaad sal word.

* Die Duitse skuld bestaan in die oortreding van die Dekaloog - en veral die 1e gebod. Deur skuld nie te koppel aan sekere benoembare oortredings nie (wat tipies Luthers is), wou Asmussen keer dat die Duitsers ook nog onder ander bindings gestel word om van hulle ware Christene te maak, soos byvoorbeeld dat hulle hul vir 'n demokrasie moet beywer. Asmussen waarsku dus teen 'dodelike wette' wette waar menslike wysheid met God se wysheid verwar word - aangesien dít die mens van sy vryheid sal beroof.

* Skuldvergewing moet onlosmaaklik deel van skuldbelydenis gemaak word. Skuldvergewing gee aan skuldbelydenis sy sin. Om hierdie rede moet skuld voor God bely word (in ' $n$ erediens) sodat die sekerheid van vergewing wel verkry kan word. Die enigste manier hoe mense van skuldvergewing verseker kan word, is wanneer dit hulle toegesê word. Hierdie toesegging van skuldvergewing is belangrik aangesien daardeur 'n nuwe, onbelaste gemeenskap tot stand kan kom.

\subsection{Die debat direk ná die oorlog}

Karl Barth, 'n genadelose kritikus van die 'Duitse Christene', was ook die Duitsers se groot vriend. In 'n brief (Koch 1990:512) in die somer van 1945 skryf hy aan die teoloë in krygsgevangenskap dat hulle medeskuldig is aan die misdaad van Hitler, maar dat hy hulle wil vergewe en 'n nuwe pad met hulle wil loop. Hy benader dus die 
probleem vanuit die perspektief van die skema 'evangelie-wet'. Die genade, die vergewing van Christus, was vir Barth daarom die begin- en eindpunt van die skuldvraagstuk. Die feit bly egter staan, dat die Duitsers volgens Barth, hulleself nie kon verontskuldig nie. Die haat teen en die verontmensliking van die Jode het die kerk en sy teoloë skuldig gemaak voor God. Die insiggewende is dat Barth nie soseer 'n skuldbelydenis verwag het nie, maar 'n erkenning dat die hele Duitse politiek, waaraan almal deel gehad het, 'n verkeerde weg was. Op 12 Maart 1945 skryf hy aan Ernst Friedlaender:

Mir liegt nicht an den Begriffen der Schuld bzw. der Kollektivschuld ... Mir liegt aber alles daran, daB die Deutschen, und zwar so oder so alle Deutschen für das seit 1933 Geschehene die Verantwortung übernehmen. Wobei es sich nicht in erster Linie um die geschehenen 'Verbrechen', sondern in erster Linie um den Weg handelt, der zu den 'Verbrechen' geführt hat .... An diesen Verbrechen als solchen mögen in der Tat nur verhältnismäßig wenig deutsche Menschen beteiligt gewesen sein. Den Weg, der dahin führte, sind sie in Form von Taten und Unterlassungen, von direkter oder indirekter Mitwirkungen, von ausdrücklicher oder stillschweigender Zustimmung ... [sind sic!] alle gegangen.

(Mehlhausen 1994:218)

Konsekwent in sy mening, skryf hy op 28 Sept 1945 aan Martin Niemöller, dat die Duitsers bloot moet erken dat hulle hulle in terme van hulle politiek misgis het (Sauter 1985:88). Op 30 Oktober 1945 word hierdie oortuiging in 'n brief aan ds Otto Fricke in Frankfurt herhaal. Hy wil hê dat die Duitsers moet bely: 'wir Deutsche haben uns geirrt, daher das heutige Chaos, und wir Christen in Deutschland waren eben auch Deutsche' (Sauter 1986b:152). Barth wou dus gehad het dat daar na die wortel van die kwaad gesoek moes word (die Bismarckse Duitse keiserryk en sy verkeerde politiek), dat dít erken moes word, en dat daar in die toekoms daarteen gewaak moes word om nie weer die selfde foute te begaan nie (Sauter 1986b:153). Hy was ook van mening dat één skuldbelydenis nie goed genoeg is nie. Die Duitsers moes volgens hom aanhou om skuld te bely. Dit moes 'n voortgaande proses wees, so nie sou dit nie 'n nuwe begin in die Duitse politieke geskiedenis moontlik maak nie (Besier 1985:36).

Ten spyte daarvan dat talle mense in veral die Belydende Kerk Barth se oordeel aanvaar het, was daar ook talle mense wat hom heftig teengegaan het. Die bekende Helmuth Thielicke was een van hulle. Volgens hom (Thielicke 1989:29-30) kan skuld 
nie eensydig bereken en uitgestal word nie. Skuld het altyd twee kante, en die Duitsers se politiek kan nie alleen die skuld kry nie. Die verdrag van Versailles het nét so 'n groot aandeel aan die chaos gehad. Skuld word volgens Thielicke voor God bely, met die verwagting dat dit vergeef sal word. Barth wil volgens hom iets anders hê. Hy wil hê dat 'n politieke oordeelsfout erken moet word, sodat dit aanhoudend in die toekoms deur diegene wat nie kan en wil vergewe nie, voor die deur van die Duitsers gelê sal kan word. Thielicke het Barth ook daarvan beskuldig dat hy skuldbelydenis misbruik om vir die wêreld te wys dat die demokrasie die ideale staatsbestel is. Op hierdie wyse word die wêreld in goeies (hulle wat hulle vir demokrasie beywer het) en slegtes (hulle wat nie in 'n demokrasie die heil kon sien nie) verdeel. 'n Skuldbelydenis kan dus volgens hom nie die begin van 'n proses wees waardeur die Duitsers verstandige politiek geleer word nie (Besier 1985:35). Indien die siekte van die ganse wêreld nie deur 'n skuldbelydenis uitgespel word nie, sou dit volgens Thielicke teologies geen waarde hê nie.

Die kerkleiding onder leiding van Asmussen het nie Barth se raad gevolg nie. Daar is besluit om as 'n daad van daadwerklike kerkleiding, skuld te bely (Sauter 1985:84-89). Dit is volgens Traub (1986:137) ook goed dat hulle Barth nie gevolg het nie, anders sou hulle regter oor hulle eie geskiedenis en profeet oor die toekoms van die geskiedenis gespeel het. Hierdie weg na die skuldbelydenis van Stuttgart was geen maklike weg nie. 'n Kort oorsig oor die kerklike gebeure direk ná die oorlog, kan ons 'n idee gee van die worsteling tot by Stuttgart.

Die gedagte dat die Duitse Kerk 'n skuldbelydenis moes aflê, het gou ná afloop van die Tweede Wêreldoorlog ontstaan. Martin Niemöller het alreeds by Treysa (die eerste 'gesamentlike sinodesitting' van die Duitse Protestante) daarop aangedring dat die Kerk sy skuld aan die Nazi-tydperk moet bely (Besier 1985:13). Niemöller se voorstel is toe deur die Lutherane verwerp aangesien hulle gemeen het dat hy dit onder druk van die Luther-vyandige Barth voorgestel het. 'n Kompromis (ter wille van kerklike eenheid) is toe aanvaar dat skuldbelydenis aan die gemeentepredikante oorgelaat sal word. Die resultaat was die volgende: Op 10 Mei 1945 het landsbiskop Theophil Wurm in Stuttgart gepreek. Hy beskuldig die politici dat hulle die land verwoes het. Hy lig die gemeente in dat die kerkleiding wel probeer oortuig het, maar dat die Nazi's nie wou luister nie. Dan verloop die preek verder volgens die Lutherse wet-evangelieskema. Die Dekaloog word gebruik om skuld te ontdek. Die gemeente doen skuldbelydenis, en die genadeverkondiging word gedoen. Belangrik is dat die biskop nie met die teodiseeprobleem worstel nie. Hy vra nie hoekom God hierdie dinge laat gebeur het nie. Hy kla nie oor die lot van die Duitsers nie en maak ook nie skuldtoewysings nie. Al wat vir hom van belang is, is die selfaanklag. Sy gemeente moet hulle skuld 
insien, omdat hulle van Christus afgedwaal het en hoofsaaklik die eerste gebod oortree het. Sy oproep tot bekering word dan uiteindelik toegespits op 'n oproep om die 'herverchristeliking' van Duitsland (Mehlhausen 1994:208-210).

In dieselfde tyd as wat die Verenigde Duitse Kerk ontstaan het, het die Ekumeniese Raad van Kerke tot stand gekom. Die lidkerke wou graag van die begin af weet wat die Duitsers oor skuld en skuldbelydenis sê. Daar is na die preke van bekende leiersfigure gaan luister en verslae en berigte is dan die wêreld ingestuur. In een van die eerste skuldbelydenisse wat die Ekumene bereik het, het ds Bodelschwinghs op 27 Mei 1945 in Bethel die volgende in sy preek gesê:

Die Christen haben Teil an der Schuld ... weder können wir noch werden wir versuchen, uns freizusprechen von der Verantwortung für die Schuld und das Schicksal unseres Volkes. Noch suchen wir uns mit der Behauptung zu schützen, daß wir von vielem, was hinter dem Stacheldraht der Lager vor sich ging oder in Polen und Rußland, nichts wußten. Diese Verbrechen waren die Taten deutscher Menschen, und wir müssen die Konsequenzen tragen.

(Besier 1985:16)

Op 16 Junie 1945 stuur Asmussen 'n preek wat hy in Halle gehou het aan die aartsbiskop van Canterbury waarin hy die volgende gesê het:

Schuldig ist die Kirche, die Kirche beider Konfessionen. Unsere Schuld liegt weit zurück. Sie besteht darin, daß wir geschwiegen haben, wo wir hätten reden sollen und redeten, wo wir hätten schweigen müssen. Wir haben durch lange Jahrzehnte versucht, mit Weltanschauungen zu praktiezieren, für welche es keine letzte Wahrheit gibt. Anstatt zu sagen 'Nein', haben wir gesagt 'Sowohl-Als'. Wir haben den Fels unseres Heiles und den Hort der Wahrheit geringgeachtet, das Wort Gottes .... Wir haben keine Zucht geübt, wo wir hätten die Sünde strafen sollen .... Schuldig ist der deutsche Bürger. Schuldig ist der Bürger, der unter allen Umständen seine Ruhe haben wollte. Schuldig is der Bürger, der um seiner Ruhe willen das Recht geopfert hat. Schuldig ist der Bürger, der bis weit in den Krieg hinein zu schweigen willens war zu allen Greueln ... Schuldig ist der Bürger, der seine Obrigkeit einen Einfluß auf seine Seele gönnte ... Ja schuldig sind wir alle, groß und klein, arm 
und reich, gebildet und ungebildet. Das Schwert und die Not kommt nicht über uns ohne Grund.

Asmussen was egter ook tipies mens. Dit was vir hom bitter moeilik om bloot skuld op hom te neem. Hy het in hierdie dae ook na verontskuldigings gesoek. Hy het, soos reeds uitgewys, gesê dat die Duitsers skuldig is - maar; hy het ook gesê dat skuld 'n mag uit 'n ander wêreld is. Van die skuld van alle Duitsers kan net gepraat word, as daar van duiwelse besetenheid gepraat word (Koch 1990:516). Hy het homself ook verontskuldig deur daarop te wys hoe baie hy gedoen het om die Nazi's teë te gaan. Asmussen kon dus nie loskom uit die worsteling om aan die een kant skuld te bely, en om aan die ander kant homself te regverdig nie (Koch 1990:516, 519).

Asmussen was nie die enigste teoloog wat 'n worstelstryd met die skuldproblematiek gehad het nie. Daar was ook ander prominente leiersfigure (veral uit Lutherse geledere) wat nie gemeen het dat 'n skuldbelydenis die laaste en bevrydende woord kan wees nie. Teen middel 1945 het Paul Althaus, baie teësinnig, toegegee dat die Duitsers skuld het wat bely moes word, maar nogtans geargumenteer dat die eintlike teologiese uitdaging dít is om die geheim van die Duitse geskiedenis te probeer ontdek. Hy het in sy preek gesê dat dit die reg van die Duitsers was om uit die kettings van Versailles (die beperkinge en onderdrukkende maatreëls wat die oorwinnaars ná die Eerste Wêreldoorlog die Duitsers opgelê het) los te breek. In die Nasionaal-Sosialisme het die Duitsers 'n Godgegewe middel gesien waardeur dit gedoen kon word. Maar dan roep hy tog uit: '.. unsere Führung hat furchtbare Fehler gemacht und schweres Unrecht begangen. Deutsche Schuld! Gewiß. Davon mußte in den letzten Wochen zuerst geredet werden, auch von dieser Kanzel'. Onmiddellik sê Althaus dan: 'Aber das kann nicht das letzte, das ganze Wort sein'. Sy worstelstryd gaan oor die vraag hoekom God hierdie verskriklike ellende oor die groot Duitse volk - met al sy groot name en ook godsdienstige prestasies - gebring het? As antwoord op sy waarom-vraag sê hy: 'Gericht Gottes - Gewiß! Aber wir kommen mit diesem Worte nicht durch. Schuld und Strafe - es geht nicht auf und reicht nicht aus. Dahinter liegt ein tieferes Geheimnis Gottes'. Wat hy met die geheim van God' bedoel, kom na vore in sy retoriese vraag waarmee hy sy preek afsluit: 'Sind wir Deutschen ein Unglücksvolk .... Hat der Schöpfer uns in seinem Zorn geschaffen, zum Unheil' (Besier 1985:19)? Hierdie houding van mense soos Althaus het weer weersin by die mense in die Ekumene gewek. Hulle het preke soos hierdie as 'n teken van onboetvaardigheid gesien. Om hierdie rede is die rug op hulle gekeer en is daar slegs met die Niemöller- groepering kontak gesoek. 
Die Duitsers het dit tot en met Oktober 1945 nie maklik gehad om hulle skuld voorbehoudloos te bely nie. Aan die een kant het die berigte oor byvoorbeeld die konsentrasiekampe begin instroom. Soos wat die gruweldade bekend geword het, het hulle geen keuse gehad as om onvoorwaardelik skuld te bely nie. Aan die ander kant het die Duitsers binne maande met die 'wet van die oorwinnaar' kennis gemaak. Hierdie 'wet' het neergekom op die vernietiging van die oorwinde. Twintig miljoen mense het 'n hongerdood in die bittere winter in die gesig gestaar, aangesien die oorwinnaars kosvoorrade aan die Duitse bevolking blokkeer het. Verder het dit spoedig bekend geword dat die Russe besig was om aan die Oosgrens mense te verskuif, te deporteer en te verwoes. In die lig hiervan skryf Heinrich Grüber dan op 1 September 1945 aan biskop Bell: 'Ich weiß' um die große Schuld, die mein Volk auf sich geladen hat, und ich werde mich nie aus dieser Schuldgemeinschaft loslösen, ich werde bis zuletzt die Sühne mittragen. Aber ich weiß um eine größere Schuld, die jetzt die Kirchen aller Welt auf sich laden' (Besier 1985:20). Die nuwe onreg van die besetters van Duitsland was 'n belangrike rede hoekom dit vir die Duitsers moeilik was om skuld te bely. Daar was by hulle ernstige kommer dat 'n skuldbelydenis hulle aan verdere willekeurige intimidasie en afpersery sou blootstel. 'n Skuldbelydenis sou hulle van hulle morele waardigheid ontneem, en hulle oorwinnaars op 'n morele troon plaas vanwaar hulle sou kon hiet en gebied en kon vertrap en verwoes, sonder dat ' $n$ vinger na hulle gewys sou kon word. Aan die ander kant was die vraag: wat gaan die konsekwensies wees indien ons dit nie doen nie? Gaan ons nie juis dán vertrap en verwoes word nie?

Die worsteling met die skuldvraagstuk het baie gou by die vraag uitgekom: wie is almal skuldig? Op 21-24 Augustus 1945 het die Rooms-Katolieke Biskopskonferensie van Fulda hierdie vraag op aandrang van kolonel Sedgwick (namens die besettingsmagte) bespreek. Op 23 Augustus het die biskoppe 'n herderlike skrywe oor hierdie saak uitgereik. Hierin bely hulle dat die kerkvolk en die kerkleiding deur die valse leer van die Nasionaal-Sosialisme betower was. Hulle bely dat talle mense onder die invloed van hierdie ideologie wandade begaan het. Maar dan sê hulle: 'Es ist eine Forderung der Gerechtigkeit, daß immer und überall die Schuld von Fall zu Fall geprüft wird, damit nicht Unschuldige mit den Schuldigen leiden müssen. Dafür sind wir Bischöfe von Anfang an eingetreten und dafür werden wir uns auch in Zukunft einsetzen' (Besier 1985:23). Die biskoppe was dus nie bereid om die hele Kerk en die hele volk skuldig te verklaar nie. Skuld kon volgens hulle nie deur 'n reglynige morele oordeel uitgewys word nie, maar moes deur die reg vasgestel word. Dít was beslis nie wat Sedgwick wou gehad het nie. As gevolg van hierdie houding van die Rooms-Katolieke, was die Protestante onder geweldige druk van die buiteland om helder en duidelik te sê dat die hele volk skuldig is. 
Dit was natuurlik nie net buitelandse druk wat Protestante tot een of ander vorm van 'kollektiewe skuldaanvaarding' gedwing het nie, maar ook mense se persoonlike cortuigings. Martin Niemöller kan hier as voorbeeld genoem word. Hy was in die tronk vanaf 1937. Maar! - soos hy direk ná die oorlog vasgestel het, is Jode al sedert 1933 verbrand en vergas. Hy het gemeen dat hy daarvan moes geweet het en dit moes probeer keer het. Hy het ook geargumenteer dat Hitler se verskoning by die eindoordeel kan wees dat niemand werklik Christus aan hom verkondig het nie. Hy, Niemöller, moes dit gedoen het (Sauter 1985:92). Onder hierdie argumente het hy geweldig baie gely. Hy het gevoel dat hy homself skuldig moes verklaar oor sy nalatingsondes. Op grond van die openbaarmaking van die feite van die corlogsmisdade het ook ander bekendes soos Heinrich Vogel, die dekaan van die teologiese fakulteit van Berlyn, die romanskrywer Ernst Wiechert en die digter Rudolf Alexander Schröder, almal as teenstanders van die Nazi-bewind, hulle mede-skuldigheid in die openbaar bely (Mehlhausen 1994:212-218). In die somersemester van 1946 het Karl Barth gehelp om die teologiese fakulteit van Bonn (vanwaar hy in 1935 verdryf is) weer op die been te bring. Vroeg in die semester het die 'evangelische' studentegemeente verklaar dat hulle nie met hulle studies kan voortgaan voordat hulle nie eers hulle skuld bely het nie. Die skriftelike weergawe van hulle belydenis lui as volg:

Wir können diese Arbeit in der Zukunft nicht fortsetzen, ohne uns
hinsichtlich der Vergangenheit ausdrücklich und ohne Vorbehalt
mitschuldig zu bekennen an der Schuld unseres Volkes, göttliche Ord-
nungen verletzt zu haben .... Wir sprechen von konkreten Schuld als
Glieder des Volkes, mit dem wir vor Gott stehen. Wir bekennen dabei
keine Schuld, die nicht Wirklichkeit wäre. Es ist Schuld geschehen ....
Wir meinen nicht, daß von dieser besonderen Schuld bei jeder Gelegen-
heit gesprochen werden müBte. Aber wir meinen, daß es einmal klar
ausgesprochen werden muB.

(Sauter 1986b:150)

Hierdie skuldbelydenisse van groot persoonlikhede en gewone studente het geweldige druk op die kerk geplaas om die gedagte van 'kollektiewe skuld' te aanvaar.

\subsection{Die Stuttgartse skuldbelydenis van 18/19 Oktober 1945}

Op grond van die bevredigende briefwisseling tussen Asmussen en Visser't Hooft het die Ekumene besluit om 'n afvaardiging na Duitsland te stuur om die nuwe kerkleiers te 
ontmoet. Hulle wou die hulpaksies met die Duitsers begin beplan; maar ook, soos Visser't Hooft in 'n brief aan Otto Dibelius geskryf het, om te luister na die skuldbelydenis van die nalatingsondes van die Duitse Kerk (Besier 1985:23-24). Ten spyte van hierdie verwagting het die afvaardiging van die Ekumeniese Raad wat na Stuttgart gereis het egter besef dat hulle 'n skuldbelydenis nie pertinent as voorwaarde vir ekumeniese ondersteuning kan stel nie. Dit sou verhoed dat 'n skuldbelydenis spontaan gedoen sou word. Vóór die sinodesitting het hulle dan aan die Duitsers laat weet dat hulle graag bande wil kom herstel, maar dat daar nog 'n onopgelosde vraagstuk is waaraan hulle aandag sal moet gee (Besier 1985:28).

Tydens die erediens op die vooraand van die sinode het dit geblyk dat daar persone onder die Duitse kerkleiding was wat gemeen het dat die Duitsers nie alleen skuld kan bely nie. Prelaat Karl Hartenstein het in sy preek daardie aand laat deurskemer dat hy meen dat daar 'n gesamentlike skuldbelydenis, van almal wat by die oorlog betrokke was, gedoen moes word (Besier 1985:29-30). Tot groot ontnugtering van Hartenstein het daar toe iets anders die volgende dag gebeur.

Op 18 Oktober 1945 het Asmussen, Niemöller en Niesel teenoor die verteenwoordigers van die Ekumene hulle persoonlike skuld asook die skuld van kerk en volk bely. Kraemer en Koechlin het egter die wens uitgespreek dat daar 'n gesamentlike belydenis namens die Evangeliese Kerk in Duitsland gedoen sal word. Die Raad het daartoe ingestem, maar versoek dat daar in hierdie belydenis van die skuld van die oorwinnaars teenoor die Duitsers melding gemaak moet word. Daar is ná debat besluit om dit nie te doen nie, aangesien daar op daardie stadium geoordeel is dat dit teenproduktief sal wees om te begin met ' $n$ proses van die berekening van skuld en teenskuld. Asmussen en Dibelius het toe elkeen 'n ontwerp gaan uitwerk. Die oggend van 19 Oktober het die Raad en die verteenwoordigers van die Ekumene weer vergader. Asmussen het toe die volgende skuldbelydenis waaroor ooreengekom is voorgelees:

Die Raad van die Evangeliese Kerk in Duitsland verwelkom by sy sitting op 18/19 Oktober 1945 in Stuttgart die verteenwoordigers van die Ekumeniese Raad van Kerke.

Ons is vir hierdie besoek besonder dankbaar, aangesien ons besef dat ons ons met ons volk, nie alleenlik in 'n groot gemeenskap van lyding nie, maar ook in die solidariteit van skuld bevind. Met groot hartseer sê ons: Deur ons is oneindige lyding oor talle volke en lande gebring. Wat ons dikwels teenoor ons gemeentes betuig het, spreek ons nou namens die ganse kerk uit: Alhoewel ons deur die loop van baie jare heen in die naam van Jesus Christus teen die gees geveg het wat in Nasionaal-Sosia- 
listiese geweldheerskappy sy uitdrukking gevind het; kla ons ons nogtans aan dat ons nie moediger bely het nie, nie getrouer gebid het nie, nie vroliker geglo het nie en nie brandender liefgehad het nie. Daar moet in ons kerk nou 'n nuwe begin gemaak word. Gegrond op die Heilige Skrif, met alle erns gerig op die enigste Heer van die kerk, gaan die kerk homself reinig van alle geloofsvreemde invloede en homself [nuut] orden. Ons hoop dat die God van die genade en die barmhartigheid ons kerk as 'n werktuig sal gebruik en aan hom die volmag sal gee om sy Woord te verkondig en aan sy wil gehoorsaamheid by onsself en ons ganse volk te wek.

Dat ons onsself by hierdie nuwe begin aan die kerke van die ekumeniese gemeenskap met hartlikheid gebonde mag voel, vervul ons met diepe vreugde. Ons vertrou op God dat die gees van geweld en vergelding, wat vandag opnuut tot uitbarsting wil kom, deur die gesamentlike diens van die kerke, gestop sal kan word en dat die gees van vrede en liefde sal regeer, aangesien die gekneusde mensdom alleen hierdeur genesing sal kan vind.

So bid ons in 'n uur, waarin die ganse wêreld 'n nuwe begin nodig het: Veni, creator spiritus!

Stuttgart 18/19 Okt 1945

$\begin{array}{lll}\text { get D. Wurm } & \text { Dr. Lilje } & \text { Dr. Heinemann } \\ \text { Asmussen } & \text { DD. Hahn. } & \text { Smend D. } \\ \text { Dr. Held. } & \text { Lic. Niesel. } & \text { Martin Niemöller } \\ \text { D. Meiser. } & \text { Dibelius } & \end{array}$

(vertaling uit Besier 1985:62)

Asmussen het nadat hy hierdie skuldbelydenis voorgelees het bygevoeg: 'ons sê dit vir $\mathrm{u}$, aangesien ons dit vir God sê. Doen alles in u vermoë dat hierdie verklaring nie polities misbruik word nie, maar tot dít dien waartoe ons dit gemeenskaplik wil laat dien' (vertaal uit Besier 1985:32). Maury het namens die Ekumene geantwoord en gesê dat hulle hierdie belydenis nie in fariseistiese trots aanhoor nie, maar voor God. Dan sê hy: 'Wir waren erstaunt, daß man in Deutschland nach der Besetzung sogleich Gerechtigkeit erwartete. Es gibt kein christliches Volk. In allen Ländern steht die Kirche im Kampf für Gerechtigkeit. Das Hitler-Regime hat die Gerechtigkeit in jedem Land vernichtet .... Nun hilft uns Ihr Wort im Ringen um Gerechtigkeit überall, auch für Deutschland' (Besier 1985:33). Wurm het toe gepraat en gesê dat daar ná die Eerste Wêreldoorlog gestry is oor skuldbelydenisse. Vandag is daar nie sprake hiervan 
nie, alhoewel hy weet dat hierdie belydenis polities misbruik kan word. Visser't Hooft het toe afgesluit en aan die Duitsers die versekering gegee dat hulle alles sal doen om te verseker dat hierdie skuldbelydenis nie misbruik sal word nie.

\subsection{Die reaksies op die Stuttgartse skuldbelydenis}

Daar is en daar kan baie beswaar teen die bewoording van hierdie belydenis ingebring word. Dit word geredelik toegegee dat die formulerings problematies is (Sauter 1985:91; Traub 1986:134-136). Hierop kan ons nie ingaan nie. Die feit bly egter staan dat hierdie skuldbelydenis geweldige reaksie uitgelok het. Daar was groot onvergenoegdheid van buitestanders. Die godsdiensafdeling van die Britse Departement van Buitelandse sake het die Duitsers daarvan beskuldig dat hierdie belydenis nie die erns van hulle harte was nie, maar dat dit net gedoen is ter wille van die buitelandse hulp. As rede is aangevoer: die kerkleiding wou nie gehad het dat hulle belydenis aan die volk bekend word nie. Hulle het gekeer dat dit in die Duitse dagpers gepubliseer word. Hanns Lilje se verduideliking was dat hierdie belydenis nie vir openbare konsumpsie bedoel was nie, maar slegs vir kerklike gebruik. Hierdie argument kon nie begryp word nie, en die beskuldiging is onmiddelik gemaak dat die Raadslede nie werklik skuld wou bely nie, maar net belang stel in selfverontskuldiging, selfregverdiging en die vergelyk van skuld (Traub 1986:138). Die Raadslede wat by Stuttgart skuld bely het, het met die argument oor die vergelyking van skuld saamgestem. Hulle was steeds oortuig dat daar eensydig skuld bely is, aangesien die ander party ook groot ongeregtighede begaan het. Asmussen het dan ook amptelik op 24 Nov 1945 die gedagte uitgespreek dat daar 'n behoefte is aan 'n gesamentlike skuldbelydenis, in die lig van die aanhoudende onreg teenoor die Duitse bevolking. Volgens Asmussen moes die gedagte dat almal sondaars is, onmiddelik in 'n nuwe skuldbelydenis uitgespel word (Besier 1985:36).

\subsection{Die verstaanshorison van hierdie skuldbelydenis}

Afgesien van die feit dat selfs die opstellers van Stuttgart om verskillende redes ongemaklik was oor hierdie skuldbelydenis, leer ons tog geweldig baie oor skuld en belydenis hieruit. Om hierdie rede wil ons na die teologiese verstaanshorison van hierdie skuldbelydenis kyk.

Stuttgart moet werklik net as 'n belydenis verstaan word. Asmussen se waarskuwing en verduideliking direk ná die voorlees van die belydenis móét 'n mens tot hierdie oortuiging bring. Hy het gewaarsku dat hierdie belydenis nie polities misbruik moet word nie, aangesien dit hier om die priesterlike diens van die ampsdraers gaan. In sy 
eie woorde: 'Ich habe als Glied des Leibes Christi meines Amtes als ein Priester zu walten, indem ich Euch das bekenne, was ich Euch bekannt habe' (Sauter 1985:63). Hanns Lilje het ook later verklaar dat Stuttgart nie as 'n publica declaratio, maar as 'n stuk binne-kerklike liturgie verstaan moet word (Sauter 1985:97). Die skuldbelydenis teenoor verteenwoordigers van die Ekumene binne 'n erediens was die belydenis dat die gruweldade van die Nazi's oortredinge van die Dekaloog was. Hierdie belydenis is met die verwagting van skuldvergewing gedoen. Inhoudelik knoop Stuttgart daarom by die ou Lutherse gedagte van die 'boete-erediens' aan (Siemens 1987:72-77).

Om skuld te bely is dus geen politieke daad nie. 'n Skuldbelydenis bring die skuld van die kerk voor die reddende en rigtende oordeel van God. Dit bely 'n gebrek aan geloof, hoop en liefde in die totale opdrag van die kerk, wat die politieke oordele van die kerk insluit, - en daarom is 'n skuldbelydenis ook 'n belydenis teenoor mense (Sauter 1985:64). Die verteenwoordigers uit die Ekumene het Stuttgart ook soos Asmussen verstaan en hanteer. Reeds op 20 Junie 1945 het daar 'n gesprek tussen die Ekumene en die professore van Göttingen plaasgevind oor die vrese dat 'n skuldbelydenis polities misbruik sou word. Die professore is by daardie geleentheid die versekering gegee dat hulle uit die Ekumene 'n skuldbelydenis nie polities sou misbruik nie. Hulle het belowe om dit nie deel van die propaganda-oorlog te maak nie. Hierdie belofte is ook gestand gedoen, en om hierdie rede kan mens sê dat ons hier met ' $n$ ware ekumeniese gebeure, verwyderd van die politieke magspel te make gehad het (Besier 1986:127).

Volgens Besier (1986:126-7) het ons hier met ware Bybels-Reformatoriese denke te make. Skuld is eenvoudig as skuld bely. Daar is nie gesoek na oorsake nie. Daar was nie 'n poging om skuldiges uit te wys nie. Ook is skuld nie teen skuld gemeet nie. Daar was slegs die behoefte om as sondaars voor God te tree. Om hierdie rede is daar nie gepoog om hierdie belydenis te verdedig en te regverdig nie. Dit was nie nodig nie, aangesien hierdie skuldbelydenis nie gesien is as die beginpunt van politieke aksies nie (Sauter 1985:118-123). Op grond van hierdie perspektief het Asmussen en ander opstellers van Stuttgart (behalwe Niemöller) hulle van die 'Darmstädter Wort' van 1947 (' $n$ verdere skuldbelydenis van die EKD) gedistansieer, omdat daardie belydenis die verwagting wou skep dat mens op grond van regte politieke moraal skuld kon vermy.

Stuttgart praat oor die 'solidariteit van 'skuld'. Hiermee is die ongelukkige term 'kollektiewe skuld', wat eintlik deur die psigoloog C G Jung aangeblaas is, vermy. Asmussen (1962:445) het op sy oudag bevestig dat daar doelbewus nie vir hierdie term gekies is nie, aangesien hulle geweet het dat hierdie term tot politieke misbruik aanleiding sou gee. Stuttgart het ook verder gegaan as die noodwendige en vanselfsprekende 'kollektiewe skaamte' - 'n term wat deur die politikus Theodor Heuss geskep is 
(Sauter 1985:104). In Stuttgart het mense uit vryheid, nie net hulle skaamte uitgespreek nie, maar ook bely dat hulle medeverantwoordelik is vir wat gebeur het. Hulle het nie die fout gemaak deur te argumenteer dat hulle ontoerekeningsbaar is nie, aangesien ' $n$ mens met so ' $n$ argument jou vryheid en uiteindelik jou menslikheid prysgee. Hulle het besef dat hulle in 'n sekere sin ook belasbaar is met die verlede. Hulle het besef dat hulle nie hulle aandadigheid kon ontken nie.

Maar, hoekom was dit vir hierdie mense moontlik om so voorbehoudloos skuld te bely? Die rede: skuldbelydenis was vir hulle ten diepste Christusbelydenis. Hulle het skuld bely met die verwagting van skuldvergewing deur Jesus Christus. Met hierdie verwagting in hulle gemoed, wou hulle maar net waarlik kerk wees, en wou die Raad 'n daad van ware kerkleiding pleeg. Hulle wou van die Duitse Kerk weer 'n ware belydende kerk maak. Hulle wou aan die lidmate wys hoe daar met skuld gehandel word. Hulle wou mense leer om waarlik skuld te bely. Hulle wou mense leer om hulle heil alleen in Christus te soek (Traub 1986:132). Hulle wou hulle lidmate leer dat dit in die kerk ten diepste gaan om die aanroeping van God in Christus. Geloof soek na genade en vergewing in 'n situasie waar daar nie van mense genade en vergewing verwag kan word nie. Dit soek na ' $n$ instansie wat verhewe is bo die aanklaers en regters van die lewe wat besig is om self onreg te bedink. Dit verbaas daarom nie dat daar in die 'solidariteit van skuld' bely is nie. Hierdie skuldbelydenis het die EKD lede nie bokant die volk verhef nie, maar juis hulle solidariteit met die volk beklemtoon. Die Raadslede het egter die grootheid van die skuld van die volk geken. Weens hierdie kennis móés hulle bely. Hulle kon bely, omdat hulle Christus as hulle Regter geken het. Hulle kon daarom ook radikaal bely. Hulle het nie net bely dat hulle morele foute begaan het nie, maar dat hulle ook teen die broederlikheid van skepsels gesondig het. Hulle het bely dat hulle politieke onreg sonde teen God was. Teenoor God kon hulle skuld bely omdat hulle geweet het dat Christus vir hulle by God intree. Christus se weldaad is om hulle van hulle verlede te bevry. Sy vergewing verhoed dat hulle verlede as deel van hulle identiteit aanhoudend aan hulle voorgehou sal word. Hy skenk hulle nuwe vryheid, vryheid om nuut te begin. In die verwagting van die koms van die Gees van Christus, kan hulle ook die wraaksug tegemoet tree wat deur hulle onreg veroorsaak is. Om hierdie rede word gesê dat 'n ware skuldbelydenis, soos Stuttgart, net 'n Christusbelydenis kan wees (Sauter 1985:66-78).

Skuldbelydenis as Christusbelydenis is ' $n$ belydenis tot God. Dit beteken egter nie dat dit daarom nie ' $n$ openbare belydenis kan wees nie. Inteendeel! Die belyers het dit juis ook as 'n belydenis teenoor die Ekumene verstaan, aangesien die Ekumene as deel van die wêreld voor God gesien is. Daar is gesê: ' '... omdat ons dit vir God sê, sê ons dit vir julle ....' Hierdie openbare skuldbelydenis wou egter sy teologiese inhoud 
behou. Dit beteken: ' $n$ skuldbelydenis put homself nie uit in die proses van 'n menslike versoeningspoging nie. 'n Skuldbelydenis begin nie met die skulderkenning van sommiges en eindig nie met die vergewing van ander nie. 'n Skuldbelydenis wil eerder sê dat almal skuldig is en in die toekoms weer skuldig sal word an 'n wedersydse gebrek aan liefde, trouheid en vertroue. Dit beteken nie dat almal maar as sondaars beskou word, en dat niemand eintlik skuldig verklaar kan word nie, maar dat die fariseisme uitgeskakel word en almal saam vreugde put uit die versoeningswerk van Christus (Sauter 1985:78-81). Hiermee word daar nie van die politiek weggehardloop nie. Stuttgart is juis radikaal 'polities'. Dit bely skuld teenoor die naaste - en veel meer en radikaal as enige ander openbare verklaring. Die skuld van 'n gebrek aan brandende liefde is 'n belydenis oor die gebrek aan naasteskap (Nächstenschaft). Stuttgart het bely dat die Duitsers sommige mense as 'mindere', ander as 'ontaarde' en ander weer as 'lewensonwaardige' mense beskou het. In die erkenning dat daar teenoor God se skepsels gesondig is, is Stuttgart 'n radikale politieke uitspraak. 'n Mens kan nie in radikaler terme skuld teenoor die naaste bely, as om teenoor God te bely dat jy sy eer as Skepper van my naaste geskend het nie (Sauter 1985:100-102; 1986b:154156).

Dit het gou aan die lig gekom dat daar 'n verstaanshorison was, waaroor daar eintlik nooit eenstemmigheid was onder die opstellers van Stuttgart nie. Die woorde: 'Nun soll in unseren Kirchen ein neuer Anfang gemacht werden' is op twee verskillende wyses geinterpreteer en uitgelê. Naas Asmussen se oortuiging dat Stuttgart 'n priesterlike karakter het, en dat dit nie primêr polities uitgelê moet word nie, was Niemöller oortuig dat dit 'n profetiese getuienis met politieke gewig teenoor die wêreld was (Honecker 1990:371). Hy het hierdie woorde só verstaan: ons het gefouteer en nou moet ons 'n weg inslaan wat sal verhinder dat ons weer skuldig sal word. Niemöller het skuld daarom ook anders as Asmussen verstaan. Hy het skuld verstaan in terme van gebrekkige verantwoordelikheid in politieke sin, aangesien mens net met hierdie argument jou solidariteit met die volk in sy skuld kan betoon. Skuldbelydenis moes volgens hom tot 'n politieke koersverandering lei. Niemöller sou dan ook in die volgende jare die skulddebat in hierdie rigting gestuur het.

\subsection{Die Duitse debat ná Stuttgart}

Die skuldbelydenis van Stuttgart het gou stil en stom geraak. Een van die redes was dat die profetiese visie van Niemöller die oorhand gekry het. Mense soos die politikus Gustav Heinemann het skuldbelydenis ook begin sien as die beginpunt van 'n nuwe, regte politieke koers, en skuld as iets wat deur korrekte politiek vermy kan word 
(Traub 1986:1391; Koch 1990:519-524). Hierdie cortuigings is dan ook op 8 Augustus 1947 in die 'Darmstadt-woord' van die Broederraad van die Evangeliese Kerk in Duitsland opgeneem. Hierdie 'skuldbelydenis' het die skuld van die Duitsers as 'n verkeerde politieke wil en handeling beskryf. Hierdie verkeerde politiek was te wyte aan vier foute. Daar is polities gedwaal, toe daar:

* Geglo is dat Duitsland die roeping het om die wêreld te genees. Hierdie geloof het die onbegrensde magspolitiek voorberei, en die volk op die troon van God geplaas;

* 'Christelike fronte' opgerig is om maatskaplike verandering te keer. Die Duitsers is skuldig weens 'n gebrek aan insig in die groot maatskaplike en politieke verskuiwings in die lewe. Daar is kamstig teen die rewolusie geveg, maar op die ou einde 'n diktatuur bevorder;

* gemeen is dat die bose met politieke middele beveg kan word; en

* nagelaat is om die saak van die armes die saak van die kerk te maak. Die belydenis is ook uitgespreek dat God se genade en vergewing hulle in staat sal stel om beter tot diens te wees ten opsigte van die ewige en tydelike heil van die lidmate (volledige teks te vinde in Smit 1990:276-277).

Ten spyte van die ophemeling van Darmstadt (Koch 1990; Stöhr 1996) is die jammerlike feit dat die Raad van die EKD hierdie 'skuldbelydenis' (wat eintlik eerder 'n verklaring is hoekom dinge gebeur het - Sauter 1986b:153) verwerp het. Die probleem is dat hierdie besluit deur ' $n$ minderheid geneem is. Van die 43 broederrade wat uitgenooi was, het net 9 opgedaag. Voor die vergadering was daar al hewige kritiek uit veral Berlyn en Brandenburg oor wat beplan word. Die teologiese beswaar was dat die kerk 'n verwronge geskiedenisbeeld, verklee in Bybelse begrippe, as teologie moes aanvaar, en dat vergewing van skuld van die aanvaarding van hierdie geskiedenisvisie sou afhang (Besier 1987:190). Honecker verwerp ook die geskiedenisvisie van Darmstadt. Hy meen dat dit eenvoudig nie waar is, dat indien mens sekere dinge nie sou doen, ander dinge noodwendig sou gebeur het nie. 'n Mens kan nie in die teologie met 'n ooreenvoudige oorsaak-werking-samhehang werk nie. Volgens Honecker kom skuldbelydenis nie neer op die toegee van politieke foute en die teologiese aanduiding van die regte politieke koers nie. Honecker (1993:216) is sekerlik reg as hy sê: 'Eine für politische Zwecke instrumentalisierte theologische Schulderklärung ist zweifellos 
fragwürdig'. 'n Gelowige bely skuld met die verwagting om van skuld vergewe te word, en nie met die verwagting om nou tot beter dade in staat gestel te word nie. Die gepraat oor skuld vanuit die perspektief van die lex accusans moet oorgaan na die behoefte aan vergewing en nie na die behoefte aan ' $n$ beter etiek nie, aangesien skuld juis op die grense van die etiek dui.

Dit is daarom teologies onverantwoordelik om skuld en skuldbelydenis met 'n eensydig sosiaal-politieke verstaan van geregtigheid of versoening in verband te bring. Wanneer versoening of geregtigheid verlaag word tot 'n blote binne-wêreldse handelingsopgawe (die ontwikkeling van begrip, die verwydering van die gevolge van onreg), dan word teologie in etiek verander. Die taak van die kerk is om van skuld en vergewing te praat, en nie van skuld en 'n beter politiek nie, aangesien alle politiek skuld veroorsaak (Honecker 1990:374-375). Teologiese argumente soos hierdie maak blykbaar nie veel indruk nie. Op 18/19 Oktober 1985 het 'n teologiese kongres 'skuld en vrede' in Göttingen Stuttgart met die volgende belydenis gedenk: 'Vierzig Jahre nach der Stuttgarter Schulderklärung erkennen wir: Wir Christen müssen gemeinsam mutig bekennen, treu beten, fröhlich glauben und brennend lieben. Sonst werden wir eine Schuld auf uns laden, die niemand mehr wird bekennen können' (Sauter 1986b: 153).

Hierdie geloof dat ons vandag polities op ' $n$ bepaalde wyse kan handel met die verwagting dat ons nie weer skuldig sal word nie, het ook 'n keersy. Dit is naamlik die geloof dat skuld slegs in die verlede te vinde is in die ou strukture, in die ou orde, in die ou politiek. Vandag in die nuwe orde, nuwe strukture en nuwe politiek, kan daar nie van skuld sprake wees nie. Volgens István Szabó (kyk Sauter 1990:498-499) het ons hier met 'n nuwe vorm van Manicheïsme - 'n nuwe dualisme - te make: die bose verlede teenoor die hemelse nuwe begin. Skuld moet daarom bely word, sodat jy aan die kant van die goeies kan kom. Volgens Sauter (1990:508-511) praat die Bybel nie oor skuld wat verhoed kan word nie, en ook nie oor skuld wat net in die verlede te vinde is nie. Om teologies korrek oor skuld te praat, moet daar oor die bede 'vergeef ons ons skulde' gepraat word. Hierdie gebed leer ons dat skuld wat vergewe is, mense bewaar om die verlede te probeer verbeter. Verder leer dit my, dat wat my vergewe is, ek nie hoef te probeer vermy nie. Hierdie gebed verdeel die mensdom ook nie in goeies en slegtes nie, maar stel almal gelyk voor God se oordeel. Hierdie gebed skenk aan jou vryheid, nie vryheid om onskuldig te word nie, maar vryheid om in die toekoms polities verantwoordelikheid te gaan handel (Sauter 1985:1005-106). 'n Teken dat jy uit die vergewing lewe, sal wees dat jy genadiglik met jou eie geskiedenis sal omgaan (Sauter 1986a:116-117). 
Die gedagte wat in die Stuttgartse skuldbelydenis uitgespreek is, dat daar van 'n 'solidariteit in skuld' sprake is, het vir talle te vêr gegaan - veral vir hulle wie gemeen het dat hulle nie skuldig was aan wandade nie. Hulle het hierdie uitspraak met 'kollektiewe skuld' verwar en gemeen dat daar nie genoegsaam tussen skuldiges en minder-skuldiges onderskei is nie. Die uitsprake van die eerste biskopskonferensie van Fulda in Aug 1945 en pous Pius XII wat die gedagte van 'kollektiewe skuld' verwerp het, is daarom verwelkom (Sauter 1986b:152; Honecker 1990:371). Toe die Nürnberg-verhore weer die aanklag maak dat die hele Duitse bevolking (ewe) skuldig is, het dit groot ontsteltenis onder die Duitse bevolking veroorsaak. Tot in die jongste verlede moes teoloë en politici teen die aanklag van kollektiewe skuld walgooi (Gestrich 1989: 289-293).

Die persoon wat die aanklag van kollektiewe skuld nog die heel beste ondergrawe het, was die bekende Heidelbergse filosoof Karl Jaspers (wat amper self deur die Nazi's vermoor is omdat hy 'n Joodse vrou gehad het). Hy het die ongeregtigheid van hierdie aanklag ingesien en uit 'pastorale bewoënheid' 'n klein boekie (1946) gepubliseer (wat op sy lesings van 1945/46 gebaseer was) waardeur hy helderheid in die vraag wou bring na die verskillende soorte skuld en verskillende kategorieë van skuldiges. In hierdie boekie het hy die volgende insiggewende onderskeidings gemaak:

* Kriminele skuldiges is mense wat skuldig is aan eenduidig bewysbare en toerekenbare oortredings. ' $n$ Regsproses is hier nodig aangesien die oortreder sy verdiende straf moet kry.

* Politieke skuldiges is mense wat skuldig is op grond van hulle owerhede en medelandsburgers se ernstige politieke foute, waarvoor hulle ook anspreeklik gehou kan word. Vir politieke skuld behoort alle betrokkenes in te staan wat die doelwitte van 'n regering ondersteun het.

* Morele skuldiges is mense wat deur hulle eie gewete skuldig verklaar word. Hulle verklaar hulle weens hulle eie houdings en dade skuldig. Morele skuld is die opgaaf van die selfbeoordeling. Mense verklaar hulle self skuldig omdat hulle sê: ek moes geweet het, ek moes getuig het, ek moes nie gestem het nie. Die gewete van die enkeling verklaar hom weens sy nalatingsondes in die lig van die tragiese .gang van die geskiedenis skuldig. Aangesien talle enkelinge hierdie worsteling deurmaak, ontwikkel daar ook so iets soos 'kollektiewe skaamte'. 
* Metafisiese skuldiges is mense wat op grond van die solidariteit van die mensdom skuldig raak. Talle gruwelike dinge gebeur waaraan ons niks kan doen nie. Tog is ons as medemense skuldig aan hierdie onreg of boosheid.

Die belangrike wat Jaspers uitgewys het, is dat ' $n$ mens duidelik tussen skuld in terme van reg, moraal en godsdiens moet onderskei (Honecker 1986:152). Op hierdie wyse verhoed Jaspers dat almal aan die een kant as kriminele gebrandmerk kan word, maar dat mense hulle aan die ander kant totaal kan verontskuldig. Hy wys met ander woorde daarop dat daar nie so iets soos 'kollektiewe skuld' is waar almal ewe skuldig is nie, maar dat mense hulle ook nie kan verontskuldig deur te sê dat ons dit nie gedoen het nie. 'Kollektiewe skuld' kan egter ook oor die vraag na die verhouding en verband tussen die skuld van die vadere en die (van die) kinders gaan.

Rainer Kessler (1996) het in sy onlangse Marburgse intreerede daarop gewys dat mens vier modelle van kollektiewe skuld in hierdie verband in die Ou Testament vind. Die eerste drie modelle hou groot gevare vir die Christelike teologie in, terwyl die laaste die aanvaarbare behoort te wees:

* Klaagliedere 5:7 sê dat die vadere gesondig het en dat die kinders daaronder ly. Hierdie woorde wat vroeg ná 587 v C geskryf is, is 'n onbetwisbare lewensfeit. Hierdie lewenswaarheid word egter godsdienstig vals wanneer die nageslag dit as selfverontskuldiging gebruik.

* Esegiël 18:20 werk weer met die konsep dat die ongeregtigheid van 'n vader nie op sy regverdige seun neerkom nie. Straf kom net oor die onregverdige. Hy alleen word gestraf. Hierdie is 'n vroeë verwerkingspoging van die katastrofe van 587 $\mathrm{vC}$ en kom neer op die verwerping van die spreuk in Esegiël 18:2 dat die straf van vadere ook op die kinders neerkom. Esegiël 18 wil dus die generasie wat die katastrofe oorleef, dus tot insig in hulle eie skuld bring. Hulle moet nie kla oor hulle lyding nie, aangesien nie die vadere, maar hulle self vir hulle eie lyding verantwoordelik is. Hierdie model skuif al die skuld dus af op die huidige generasie waar die die vorige model hierdie generasie weer wou verontskuldig. Juridies (Deut 24:16) is hierdie model begryplik en geldig. Buite juridiese verband word hierdie waarheid egter betwyfel. Die wysheidsliteratuur wys byvoorbeeld op die onreg van die lewe dat goeies nie net goeie dinge ontvang, en dat slegtes nie altyd hulle regverdige straf ontvang nie. 
* 1 Konings 8:46 werk met die insig dat almal sondaars is. Ook hierdie stelling is waar (veral uit die perspektief van die 'erfsondeleer'). Op grond van hierdie waarheid is dit eintlik 'n noodwendigheid dat daar van 'kollektiewe skuld' gepraat moet word. Volgens Kessler gee hierdie model ook aanleiding tot verontskuldiging, deurdat skuld gerelativeer word. Jou eie skuld word in 'n beter lig gestel deur daarop te wys dat ander ook skuld het.

* Psalm 106:6 wat sê 'ons het gesondig net soos ons vaders', is vir Kessler die mees bruikbare model. Hierdie model verhoed die vorige verontskuldigings wat skuld verplaas na of die vaders, of die kinders, of alle mense. Kessler meen dat die teologie by die na-eksiliese teologie soos Daniël 9:4-19, Esra 9:6-15, Nehemia 1:5-11 en Nehemia 9:5-37 moet aansluit, deur elke geslag op sy eie en werklike skuld te wys. Net op hierdie wyse sal daar op 'n korrekte wyse van 'kollektiewe skuld' gepraat word. Die korrekte wyse is om te verhoed dat 'kollektiewe skuld' nie in 'n selfregverdigings- en selfverontskuldigingsmeganisme omslaan nie. Die skuld van die vadere behoort slegs in herinnering gehou te word, sodat die huidige geslag nie dieselfde fout begaan nie.

' $n$ Volgende vraag wat in die Duitse teologie gedebatteer word, is die vraag na die vas stelbaarheid van skuld in die geskiedenis. Wanneer daar sprake is van die 'solidariteit in skuld', moet daar geweet word wat hierdie skuld is en wat die oorsprong daarvan is. Eilert Herms (1988:353) wys daarop dat skuld in die reg en in die alledaagse lewe vas gestel en uitgewys word wanneer daar aan die volgende vier kriteria voldoen word:

* Wanneer die handeling van 'n enkeling op 'n reëlmatige wyse met gevolge verbind kan word;

* wanneer hierdie gevolge as gevolge van 'n bepaalde handeling van 'n individu geïdentifiseer kan word;

* wanneer die handelingsubjek die gevolge voorsien het en dit dus kon vermy het. Hy moet daarom vir die gevolge verantwoordelikheid kan neem; en

* wanneer daar duidelike etiese maatstawwe is waarvolgens vasgestel kan word of hierdie verantwoordelikheid korrek waargeneem is of nie.

Skuld kan egter nie so maklik 'in die geskiedenis' uitgewys word nie, soos wat die sogenaamde 'Historikerstreit' in Duitsland bewys het (Herms 1988:354-357). Tog 
meen Herms dat die teologie wel 'n bydrae in hierdie verband te lewer het. Die gerigsprofete en Bybelse geskiedskrywers het die ondergang van Israel nie as noodlot, maar as straf op skuld (Deut 11:26-28; Spr 14:34) verstaan. Maar wie was hierdie skuldiges, en wat was hulle skuld wat vir hierdie ondergang verantwoordelik was? Die profete wys daarop dat dit veral die politici, die invloedryke ekonome en die valse profete (met hulle booshede) was wat as die skuldiges geïdentifiseer kan word (Amos 4:1, 5:10; Miga 2:1; Jes 1:23; 5:8; Jer 6:13; 23:11; 33:23). Die gevolgtrekking: die skuld van hulle in regeerposisies kan geïdentifiseer word as oorsaak van historiese katastrofes. Skuld word volgens die Ou Testament ook nie net dán uitgewys wanneer mense se dade negatiewe gevolge opgelewer het nie, maar ook dán wanneer mense in regeerposisies nie kon of wou insien dat hulle planne en dade negatiewe gevolge sou oplewer nie. Iemand word dus volgens die Ou Testament skuldig wat nie in staat is om die gevolge van sy handelinge raak te sien nie. Trouens! Iemand wat nie die gevolge van sy handelinge kan insien nie, kan en mag nie regeer nie. Die Bybelskrywers het egter ook besef dat die verskillende regeerinstansies in mekaar verstrengeld is. Daarom sal invloedrykes uit verskillende sfere van die samelewing skuldig wees aan bepaalde wanontwikkelinge. Nie net enkelinge kan ná 'n katastrofe as skuldiges uitgewys word nie, maar die hele skuldnetwerk moet openbaar gemaak word. In hierdie sin is daar in die Ou Testament sprake van 'kollektiewe skuld' - die gemeenskaplike skuld van die regeerders en invloedrykes van 'n bepaalde regeertydperk (Herms 1988:357-363).

Die volgende vraag wat in die gemoed opkom, is: is staatsamptenare, werkers van 'n maatskappy of lidmate van 'n kerk skuldig wanneer hulle regeerders, werkgewers en leiers ernstige sondes begaan? Is daar ook in hierdie sin van 'kollektiewe skuld' sprake? Martin Honecker beantwoord hierdie vraag aan die hand van die konsep 'verantwoordelikheid'. Honecker (1993:220-226) meen dat daar van 'kollektiewe skuld' sprake is wanneer daar van kollektiewe verantwoordelikheid sprake is. Daar kan van kollektiewe verantwoordelikheid sprake wees, wanneer daar van kollektiewe handeling sprake is. Hy wys daarop dat die ou Romeinse regsreël societas delinquere non potest - 'n organisasie/samelewing/onderneming as sodanig kan nie krimineel word nie vandag onhoudbaar geword het. 'n Maatskappy kan gedagvaar word vir onwettige handel in wapens, ekologiese skade ensovoorts.

Vandag word nie net natuurlike persone, maar ook regspersone strafregtelik tot verantwoording geroep. Hy wys daarop dat maatskappye, partye, volke en kerke ook kollektiewe handelaars is, en daarom kollektiewe verantwoordelikheid dra en uiteindelik kollektief skuldig kan raak. Juis dié kerke wat volkskerke is, word medeskuldig aan die foute van die politici, aangesien hulle by die politieke strukture aanpas en inpas. Indirek en of direk bevorder hulle bepaalde politieke doelwitte wat later as 
gruwelike foute uitgewys kan word. In hierdie sin het die hele Duitse Kerk homself tydens die Tweede Wêreldoorlog skuldig laat word. Máár! Wanneer daar van kollektiewe handelingsubjekte gepraat mag word, beteken dit egter nog nie dat die kollektief die gewete van die enkeling word nie. Daar bestaan eenvoudig nie só iets soos 'n kollektiewe gewete nie (Honecker 1993:227). Individue is vry en kan wel anders handel as wat van hulle verwag word. Elke individu staan elke dag met sy gewete alleen voor God se aangesig. Die primêre skuld word daarom tog op die skouers van die enkeling geplaas. Ook hierdie tipe van 'kollektiewe skuld' kan dus nie as 'n relativeringsmeganisme vir eie skuld gebruik word nie.

Hierdie geworstel met 'kollektiewe skuld' het die Duitsers tog by 'n gebalanseerde siening oor skuld uitgebring. Een voorbeeld word genoem. Op 9 November 1988 het die Kerk 'Reichskristallnacht' (dié nag waarop die Jodevervolging begin het) van 9 November 1938 herdenk. By hierdie geleentheid is daar afstand gedoen van die konsep 'kollektiewe skuld'. Daar is aan die een kant gepraat van die gevolge van die verlede wat nog swaar op Duitsland rus. Aan die ander kant is daar gepraat van die identifiseerbare skuld wat ook op die kerk rus as gevolg van die mislukking in verantwoordelikheid. Hierdie mislukkings in verantwoordelikheid waardeur die Duitse Kerk skuldig geword het, kom neer op die feit dat hulle toegelaat het dat die probleem van die Jode hulle ekklesiologie bepaal het, dat hulle toegelaat het dat die staat die publieke mening onderdruk het, en dat hulle toegelaat het dat die regspraak verwring is wat gelei het tot die ontmensliking van mense (Rendtorff 1989).

Die skulddebat in Duitsland het ook 'n ander gesig. Mense soos Paul Althaus (na wie reeds verwys is) het ook geweldige invloed op die openbare en teologiese meningsvorming uitgeoefen. Althaus het die gedagte van skuldbelydenis nie hoog aangeslaan nie. Hy wou die Duitse problematiek deur 'geskiedenisteologie' hanteer (Sauter 1985:110-118). Rudolf Bohren (1986:216-221) wys aan die hand van Althaus se preke ná die oorlog op die minagting wat hy vir die skuldgedagte entwikkel het. Hy het ten spyte van sy aanvanklike belydenis van skuld toenemend begin om Duitsers te verontskuldig, om op die skuld van andere te wys, en om selfs ander volke soos die Pole as die eintlike misdadigers af te maak. Auschwitz het hom nie ontstel nie, maar wel die magsverlies van Duitsland. Vir skaamte en rou was daar geen plek in sy prediking nie.

Op grond van Althaus en sy vriende soos Werner Elert se prediking het Alexander en Margarete Mitscherlich 'n boek geskryf, getiteld Die onvermoë om te treur. In hierdie boek het hulle angetoon dat die tema skuld nie vir lank konjunktuur binne die Duitse teologie geniet het nie. In 1986 beskryf Wolfhart Pannenberg dan die Duitse geestesklimaat as koud teenoor die skuldtematiek. Hy wys daarop dat Nietzsche en 
Freud (en saam met hulle miljoene Duitsers) al lankal in opstand was teen die wek van skuldgevoelens deur die Protestantse wetsprediking. Hy wys daarop dat die Duitse samelewing geen boetementaliteit meer het nie. Om hierdie rede is hy daarvan oortuig dat die skuldbesef nie meer as kriterium vir die waarheid van die evangelie kan geld nie. Net 'n oortuigende beantwoording van die vraag na God kan die evangelie nog red. Pannenberg is sekerlik minstens in sy waarneming van die geestesklimaat korrek. Die volgende woorde van die filosoof Nicolai Hartmann kan ons 'n idee gee van die sonde-vyandigheid van die wêreld: 'Die Sehnsucht nach Erlösung ist ein Zeichen inneren Bankrotts. Die Religion baut ihr Erlösungswerk gerade auf diesem Bankrott, dem moralischen Gebrochensein, auf. Die Erlösung entmündigt den Menschen tatsächlich, mutet ihm die Preisgabe der Freiheit zu ... Sei schuldig, so viel du willst, und trage die Schuld in Ehren, nur Sorge, daß Gute geschehe' (Hartmann, in Honecker 1990:374).

Sauter (1990:502-505) is ook van oortuiging dat die skuldtema vandag op wankelende bene staan. Hy wys weer daarop dat die 'tragiese bewussyn' vandag mense se lewens beheers. Mense is vandag (saam met die ou Grieke) daarvan oortuig dat skuld en noodlot ineengestrengeld is. Hulle glo dat mense onder bepaalde omstandighede net op sekere maniere kan handel, aangesien hulle nie uit die situasie kan wegvlug nie. Op hierdie wyse verontskuldig mense hulle weer, deur te argumenteer dat jy eintlik maar net ' $n$ slagoffer van jou omstandighede is. Sauter (1986a:109-111) wys ook daarop dat mense vandag onder die tirannie van die psigoterapeute lewe wat alles moontlik doen om hulle daarvan te oortuig om hulleself van skuld en skuldgevoelens te bevry, met al die psigiese probleme wat dit nou ook weer skep.

Tog is die wêreld vol van skuldtoewysings. Volgens Honecker (1990:370-375) wil en kan die wêreld nie meer oor skuld en sonde praat nie (Heinrich Heine, Friedrich Nietzsche en Gottfried Benn), maar tog wil almal skuldbelydenisse aanhoor. Michael Beintker (1995:139) wys ook daarop dat die wêreld nie (meer) oor skuld vanuit 'n Christelike perspektief dink nie, maar nogtans op openbare skuldbelydenisse aandring. Skuld is nie meer 'n saak van elke dag nie, aangesien dit net ter sprake kom waar daar groot maatskaplike veranderinge plaasvind. Net dár waar mense kla dat hulle gely het, word daar nog oor skuld gepraat. Net sekere gebeure en sekere mense word daarom met skuld verbind. Hulle wat skuldig is, moet gevind word sodat hulle in die openbaar kan kom bely voor die klaers wat ook die regters is. Wat bely moet word, kan tuisgebring word onder die heuristiek van die nalating en mislukking in roeping. Agter alles lê die verlange na aardse geregtigheid (iustitia civilis), wat telkens gou omslaan in sensasielus en politieke berekendheid, asook die morele verwaandheid dat (slegs) sekere 
mense presies weet wat goed en sleg is. Die ironie is egter dat mense hulle nie onderworpe aan hierdie aardse regters voel nie. Om hierdie rede verskuif die ware skulddebat vanaf die etiek en godsdiens na die reg (Beintker 1995:139-142).

Die huidige skulddebat wat van God losgekoppel is, lewer geen bydrae tot die oplossing van probleme nie. Beintker is reg as hy vra dat skuld weer in samehang met die regverdigingsleer gebring moet word. Net die regverdigingsleer sal mense weer so ver kan bring om te sê: my skuld is my skuld. Dit sal die aanhoudende neiging tot skuldtoewysing demp. Dit sal skuld van moralisme help onderskei. Hierdie leer sal ons daarvan bevry om aardse geregtigheid met genade te verwar. Dit sal ons leer dat die gemeente die plek is waar skuld bely moet word, aangesien net dáár die sirkel van selfgeregtigheid en onskuldswaan verbreek, en waar 'n mens van die tirannie van moralisme bevry kan word (Beintker 1995:144-151; Van Wyk 1990). Skuld is vir gelowiges ' $n$ godsdienstige saak. Daarom is dit vir hulle 'n saak voor God in die erediens (Honecker 1986:158). 'n Ware skuldbelydenis is dus 'n godsdienstige daad wat onlosmaaklik met boete, vergewing en verlossing saamhang. Dit is daarom 'n daad van die geloof. Om hierdie rede kan 'n skuldbelydenis nie georganiseer, opgevoer of afgedwing word nie (Honecker 1990:373). Die kerk moet nie die gesprek van die samelewing herhaal nie. Sy saak is die verkondiging van Jesus Christus en sy genade. Maar, jy kan nie genade verkondig en oor skuld swyg nie (ook die skuld van die vadere), aangesien Christusprediking prediking oor skuld én sonde is (Bohren 1986:209). Indien daar nie oor eie skuld en skuld van die vadere gepreek wil word nie, sal die waarheid van die volgende stelling 'Der Unfähigkeit, Gott zu fürchten, entspricht die Unfähigkeit zu trauern' (Bohren 1986:210), een of ander tyd in die lewe van 'n kerk ontbloot word.

\subsection{Samevatting en konklusie}

Teoloë van die Duitse Evangeliese Kerk het tydens die Tweede Wêreldoorlog al besef dat die kerk hom skuldig gemaak het aan oortredings van die Dekaloog. Hulle het geweet dat die kerk skuld sal moet bely. 'n Skuldbelydenis het ná die oorlog nie maklik gekom nie. Die neigings tot selfregverdiging, verontskuldiging en die vergelyking van skuld het dikwels oorhand gekry. Tog het minstens die kerkleiding besef dat daar skuld bely móés word. Hulle verstaan van die Bybels-Reformatoriese teologie het dit 'n noodwendigheid gemaak. Dít is binne 'n erediens voor en teenoor verteenwoordigers uit die Ekumene gedoen. Niemand het destyds en sal vandag daardie manne se godsdienstige integriteit bevraagteken nie. Hulle skuldbelydenis het egter talle vrae laat ontstaan waaroor daar tog mettertyd duidelikheid gekom het. Vandag weet almal dat 
nie alle Duitsers ewe skuldig is nie. Hulle wat in regeerposisies was, moet die meeste skuld dra. Tog word besef dat alle Duitsers in 'n mindere of meerdere mate met skuld belas is. Die meeste Duitsers weet dat hulle skuld vergewe is. Tog is daar groepe wat meen dat hulle hulleself onskuldig moet maak deur die regte politiek te beoefen. Op hierdie wyse speel hulle in die hande van hulle wat niks met die Christelike geloof te make wil hê nie, maar nogtans sekulêre skuldbelydenisse wil aanhoor om daardeur hulle morele meerderwaardigheid te demonstreer. Wat die kerk in hierdie situasie kan en moet doen is om die 'erfsonde-dogma' sonder ophou te verkondig. Hierdeur sal minstens die kerkvolk gedwing word om weer met skuld vanuit die perspektief van die regverdigingsleer om te gaan.

\section{DIE AFRIKAANSE KERKE - APARTHEID - SKULDBELYDENIS}

Mense soos N P Van Wyk Louw (1986) het alreeds in 1939 besef dat solidêre kritiek binne die Afrikanerdom baie nodig is. Alreeds toe het hy besef dat die Afrikaner oor skuld en euwels van die volk gewaarsku moet word. Sy kritiek is egter as volksverraad gesien. Nou is kritiek te laat. Kain het klaar vir Abel doodgeslaan. Nou is dit net die skuld en die skande wat bly. Duitsers soos Stöhr (1996) en Scharfenberg (1989) waarsku ons om met die skuldvraagstuk af te handel, so nie gaan ons net soos hulle, onder ons kinders nog baie (o a sielkundige) probleme ondervind. Breyten Breytenbach (1996:7) is korrek dat ons hierdie probleem binne Afrikaner-geledere dringend sal moet oplos.

Die sinodes en kerkleidings van die Afrikaanse kerke het besluit om hierdie probleem te hanteer deur nie in die openbaar skuld te bely nie. Hierdie besiuit gaan deur talle as 'n houding van onboetvaardigheid geïnterpreteer word. Aan die ander kant bely sekere individue en groepe geestelikes hulle skuld in die openbaar. Hulle optrede is ook onder verdenking. Hierdie belydenisse in die openbaar word gesien as 'n meganisme waardeur ware skulderkenning omseil word en as 'n geleentheid vir mense om met hulle morele goedheid te spog.

Ons moet egter nie moedeloos en ontnugter wees nie. Ons is nie anders as ander mense nie. As voorbeeld kan die volgende insident uit die onlangse verlede genoem word: In 1962 is Adolf Eichmann in Jerusalem tereggestel. Martin Buber het gesê dat dit 'n groot fout is, aangesien die jong Duitsers wat hulle skuldig voel nou kan meen dat die skuld versoen is. Hannah Arendt het egter weer gesê dat die Eichman se teregstelling nie saak maak nie, aangesien die sogenaamde skuldgevoelens van die Duitse jeug oneg is en niks beteken nie. Hulle sogenaamde skuldgevoel is niks anders as selfontlasting en 'n weghardloop van die etiek nie. Sy het gesê dat almal dit maar moet 
weet dat berou en skaamte baie selde in die lewe voorkom. Dit is die harde (godsdienstige) werklikheid van die lewe (Pöhlmann 1986:101). Arendt is nou nie die eerste persoon wat tot hierdie ontdekking gekom het nie. Calvyn (Inst III, 4, 10-11) het ook al geweet dat skulderkenning nie outomaties op skuld volg nie. Hy het geweet dat skulderkenning 'n genadegawe van God is. Wat kan en moet die kerke dan doen in die lig van hierdie werklikheid? Ek meen dat Bohren (1986:211-212) reg is dat die kerke minstens die taak het om die erfsonde-dogma te verkondig. Massamoorde word gepleeg, goedgepraat en toegelaat wanneer mense nie meer hulle eie verborge boosheid ken nie. Wanneer mense in hulle eie goedheid en in die goedheid van hulle politieke ideologieë glo, is hulle tot boosheid instaat. Luther was reg toe hy gesê het dat mense hulle daadsondes maar aan die duiwel kan toeskryf, maar dat hulle moet besef dat hulle aan die erfsonde skuldig is. Die groot Russiese skrywer Dostojewskij (Kraus 1993:96109) het in sy vier wêreldberoemde romans mense tot die insig probeer bring dat moord en doodslag in elke mens sluimer. Elke mens is 'n potensiële moordenaar omdat hy hom van God afwend en daarom sy medemens begin te haat. En dít gebeur elke dag van ons lewens. Om hierdie rede moet skuldbelydenis die sentrum van die liturgiese en daaglikse erediens wees. Wanneer ware skuldbelydenis deel van elke dag se lewe is, kan ons dalk ' $n$ bydrae lewer om van die wêreld 'n beter plek te probeer maak. Ek sê ons het minstens die taak om die erfsonde-dogma te verkondig. Die taak om binne-kerklik oor ons historiese skuld te praat lê nog voor.

\section{Literatuurverwysings}

Asmussen, H 1962. s v Stuttgarter Erklärung. RGG VI.

Beeld, 16 April 1996, Die Waarheids-en Versoeningskommissie, bl 1, 6, 8 en 13.

Beeld, 23 April 1996. Die Waarheids-en Versoeningskommissie, bl 6.

Beeld, 25 April 1996. Die Waarheids- en Versoeningskommissie, bl 13.

Beeld, 3 Mei 1996. Die Waarheids- en Versoeningskommissie, bl 7.

Beeld, 8 Mei 1996. Die Waarheids- en Versoeningskommissie, bl 6.

Beeld, 6 Junie 1996. IVP 'wil niks met WVK te doen hê', bl 2.

Beeld, 11 Junie 1996. Leraar vertel hoe briefbom sy hande, oog geëis het, bl 2.

Beeld, 17 Junie 1996. 'Oortreders moenie wag om skuld te bely nie': Slagoffers se geduld gaan opraak, sê biskop, bl 13.

Beeld, 26 Julie 1996. Die Waarheids- en Versoeningskommissie, bl 4.

Beeld, 8 Aug 1996. Die Waarheids- en Versoeningskommissie, bl 4.

Beeld, 9 Aug 1996. 'WVK neem die plek van rituele in', bl 17.

Beeld, 27 Aug 1996. 'Nee vir vervolging, ja vir vergifnis', bl 11.

Beeld, 17 Sept 1996. Moordenaar De Kock doodkalm, helder, bl 1 en 2.

Beeld, 16 April 1997. Afrikaner nie by WVK beskuldig - Mandela, bl 1. 
Beeld, 17 April 1997. Die Afrikaner, b1 14.

Beeld, 23 Mei 1997. NG Kerk sê nee vir voorlegging aan WVK, bl 1.

Beeld, 13 Junie 1997. '7000 het gesterf in apartheidstaat se oorlog' teen jeugdiges, bl 2.

Beintker, M 1995. Neuzeitliche Schuldwahrnehmung im Horizont der Rechtfertigungsbotschaft, in Beintker, $\mathrm{M}$ en ander (Hrsg), Rechtfertigung und Erfahrung: Festschrift für Gerhard Sauter zum 60. Geburtstag, 137-152. Gütersloh: Kaiser.

Besier, G 1985. Zur Geschichte der Stuttgarter Schulderklärung von 18./19. Oktober 1945, in Besier, G \& Sauter, G (Hrsg), Wie Christen ihre Schuld bekennen: Die Stuttgarter Erklärung 1945, 9-61. Göttingen: Vandenhoeck.

— 1986. 'Durch uns ist unendliches leid über viele Völker und Länder gebracht worden': Schulderkenntnis und Schuldbekenntnis in der Geschichte unseres Jahrhunderts. GlLern 1, 120-129.

1987. Zur ekklesiologischen Problematik von 'Dahlem' (1934) und 'Darmstadt' (1947). KuD 33, 178-191.

Bohren, R [1980] 1986. Predigtlehre. 5. Aufl. München: Kaiser.

Bonhoeffer, D [1949] 1966. Ethik. 7. Aufl. Zus. und hrsg v Bethge, E. München: Kaiser.

Breytenbach, B 1996. Net soepel Afrikaners sal oorlewe - Breyten: 'Reënboognasie is 'n optiese frats wat blom', Beeld, 8 Okt 1996, bl 7.

Calvyn, J [1559] 1988. Institusie van die Christelike godsdiens, Band 3, vertaal deur W H Simpson. Potchefstroom: CJBF.

De Beer, P 1996. Wat sal ons kinders daarvan sê? Konteks 7, bl 4.

De Gruchy, J 1993. Guilt, amnesty and national reconstruction: Karl Jaspers: Die Schuldfrage and the South African debate. JTSA 83, 3-13.

Deist, F 1993. Sorry, Sam. Pretoria: Van Schaik.

1996. Vergewe én onthou, Die Kerkbode, 15 Nov 1996, bl 9.

De Villiers, E 1996. The challenge to the Afrikaans Churches, in Botman, H R \& Petersen, R M (eds), To remember and to heal: Theological and psychological reflections on truth and reconciliation, 140-153. Cape Town: Human \& Rousseau.

De Villiers, I 1996. Punte van versoening. Rapport. 8 September 1996, bl 22.

Die Kerkblad, 29 Januarie 1997. Gereformeerdes neem nie deel aan politieke skuldbelydenisse nie, bl 7 .

Die Kerkbode, 16-Aug 1996. 'NG Kerk het duidelik oor apartheid gepraat', bl 1.

Die Kerkbode, 18 Okt 1996. Ons het geswyg toe ons moes getuig - NGK-ring, bl 1.

Die Kerkbode, 15 Nov 1996. Tutu gaan nie sê hy is jammer oor sanksies, bl 20.

Die Kerkbode, 20 Junie 1997. Sienings: Ope brief aan predikante van Beyers Naudé, bl 6. 
Du Plessis, J 1997. WVK laat skille van Afrikaner se oë afval: Ontnugtering met sy kerk, kultuurleiers en NP-verlede. Rapport, 12 Januarie, 1997, bl 13.

Engelbrecht, B 1996. Hou op sanik oor NGK en apartheid. Die Kerkbode, 18 Oktober 1996, bl 10.

Esterhuyse, W 1996. SA móét deur die WVK-proses. Beeld, 20 April 1996, bl 14.

Gestrich, Chr 1989. Die Wiederkehr des Glanzes in der Welt: Die christliche Lehre von der Sünde und ihrer Vergebung in gegenwartiger Verantwortung. Tübingen: Mohr.

Giliomee, H 1996a. Die las van die verlede: Ons moet verby apartheid kyk. Beeld, 26 Maart 1996, bl 9.

1996b. Die kommissie vir waarheid is geen plek vir biegtery: Die Afrikaner sal 'n ander plan moet maak. Rapport 3 November 1996, bl 21.

Herms, E 1988. Schuld in der Geschichte: Zum 'Historikerstreit'. ZThK 85, 349-370. Honecker, M 1986. Geschichtliche Schuld und kirchliches Bekenntnis. ThZ 42, 132158.

1990. Einfuhrung in die theologische Ethik. Berlin: De Gruyter.

1993. Individuelle Schuld und kollektive Verantwortung: Können Kollektive sündigen? ZThK 90, 213-230.

Jaspers, K 1946. Die Schuldfrage: Zur politischen Haftung Deutschland. Heidelberg: Schneider.

Jonker, W 1991. Die noodsaak van skuldbelydenis, in De Villiers, E \& Kitching, D (reds), Derdegelui vir môre, 94-102. Kaapstad: Tafelberg.

Jordaan, G 1996. Nuwe SA voor Waarheidskommissie? Die Kerkbode, 8 Nov 1996, bl 5.

1997. Leraars moet voor WVK bely. Algemene Kerkbode, 13/14 Junie 1997, bl 5.

Kessler, R 1996. Das kollektive Schuldbekenntnis im Alten Testament. EvTh 56, 2943.

Koch, D 1990. Geschichtliche Schuld und Neuanfang. EvTh 50, 511-524.

König, A 1996. 'n Belydenis met trane van ons gebrokenheid: NG Kerk se biegredes pas nog nie by die sonde nie. Beeld, 22 Okt 1996, bl 9.

Koornhof, H 1996. Die WVK en ons: Dis 'n tyd vir verootmoediging en gebed. Die Kerkbode, 16 Aug 1996, bl 14.

Kraus, H-J 1993. Schuld und Vergebung in F M Dostojewskijs Werken. EvTh 53, 96109.

Latakgomo, J 1996. Dilemma van WVK: Hy dryf nasie uiteen. Beeld, 9 November 1996, bl 6.

Le Roux, A 1996. Askies, Maria? Wellington: Protea.

Loader, J 1997. Vlek soos Israel die hele verlede oop. Beeld, 15 Mei 1997, bl 14. 
Mehlhausen, J 1994. Die Wahrnehmung von Schuld in der Geschichte: Ein Beitrag über frühe Stimmen in der Schulddiskussion nach 1945. EvTh 1994, 201-219.

Meiring, P 1996. Om rustig te slaap: Genesing agter trane by WVK. Beeld, 27 Augustus 1996, bl 10.

Müller, B A 1993. Psalm 32, in Burger, C W et al (reds), Riglyne vir prediking oor regverdiging en reg, 171-180. Kaapstad: Lux Verbi. (Woord teen die lig III/3.)

Müller, J 1996. NGK behoort skuldbelydenis voor WVK te doen. Die Kerkbode, 6 September 1996, bl 13.

Muller, P 1996. Biegkommissie slaag nog nie toets. Rapport, 14 Julie 1996, bl 15.

Pannenberg, W 1986. Protestantische BuBfrömmigkeit, in Christliche Spiritualität:

Theologische Aspekte, 5-25. Göttingen: Vandenhoeck. (KVR 1519.)

Peters, A 1984. BuBe - Beichte - Schuldvergebung in evangelischer Theologie und

Praxis, in Peters, A, Rechenschaft des Glaubens: Aufsätze, 209-238. Göttingen:

Vandenhoeck.

Pöhlmann, W 1986. Wohin führen Schuldgefühle? GlLern 1, 101-105.

Rapport, 27 Oktober 1996. Die nuwe slagoffers, bl 14.

Rapport, 13 Oktober 1996. Die Afrikaner-hart gaan uitgeruk word: Polisie se getuienis kan talle moorde oplos, bl 7.

Rendtorff, T 1989. Schuld und Verantwortung 1938/1988: Gedanken zum christlichen Umgang mit der Vergangenheit. ZThK 86, 109-124.

Sauter, G 1985. 'Vergib uns unsere Schuld...': Eine theologische Besinnung auf das Stuttgarter Schuldbekenntnis, in Besier, G \& Sauter, G (Hrsg), Wie Christen ihre Schuld bekennen: Die Stuttgarter Erklärung 1945, 63-128. Göttingen: Vandenhoeck.

1986a. Schulderkenntnis in der Bitte um Vergebung. GlLern 1, 109-119.

1986b. Die Stuttgarter Schulderklärung 1945 - ein Wendepunkt im Verhält-

nis der deutschen evangelischen Kirche zur Politik? Una Sancta 2, 150-158.

1990. Bekannte Schuld. EvTh 50, 498-511.

Scharfenberg, J 1989. Welchen Sinn hat es, von Schuld zu sprechen? EvKomm 22, 40-42.

Siemens, A 1987. Unbelastete Gestaltung der Zukunft: Verdrängte Zusammenhänge des Stuttgarter Schuldbekenntnisses. KuD 33, 60-92.

Smit, D J 1990. Jakobus 5:16, in Burger, C W et al (reds), Riglyne vir prediking oor vrede, 271-281. Kaapstad: Lux Verbi. (Woord teen die lig III/I.)

1995. The Truth and Reconciliation Commission - tentative religious and theological perspectives. JTSA 90, 3-15. 
Smit, D J 1996. Confession - Guilt - Truth - and - Forgiveness in the Christian Tradition, in Botman, H R \& Petersen, R M (ed), To remember and to heal, 96117. Cape Town: Human \& Rousseau.

Smit, N 1997. Wat het ons vir ons tyd te sê? Die Kerkblad, 29 Januarie 1997, bl 10 en 11.

Stöhr, M 1996. Dealing with the past in a just way. JTSA 96, 20-33.

Thielicke, H 1989. Die geistige und religiöse Krise des Abendlandes: Exkurs über Karl Barth. EvKomm 22/9, 27-30.

Traub, H 1986. Das Stuttgarter Schuldbekenntnis - und was daraus wurde. GlLern $1,131-140$.

Van der Walt, B J 1996a. Responsibility, conversion, confession, forgiveness, restitution and reconciliation. Potchefstroom: IRS. (Series F1 no 337.)

1996b. Die Waarheids- en Versoeningskommissie: 'n Kontradiksie op sigself of prinsipieel noodsaaklik?, in Van der Walt, B J \& Van der Walt, T (ed), Die Waarheids- en Versoeningskommissie, 1-21. Potchefstroom: IRS. (Reeks F1 no 342.)

Van Wyk, I W C 1990. Dié skuldbelydenis 'n vrug van moralisme. Die Hervormer 15 Desember 1990, bl 5.

Van Wyk, J H 1997. Gedagtes oor skuldbelydenis. Die Kerkblad, 26 Maart 1997, bl 24 en 25.

Van Wyk Louw, N P [1939] 1986. Lojale verset: Volkskritiek, in Van Wyl Louw, Versamelde Prosa. Deel 1, 166-168. Kaapstad: Tafelberg. 